Atmos. Chem. Phys., 18, 13265-13281, 2018

https://doi.org/10.5194/acp-18-13265-2018

(C) Author(s) 2018. This work is distributed under

the Creative Commons Attribution 4.0 License.

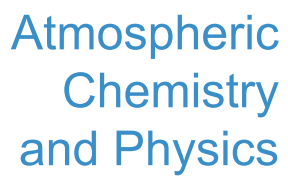

(c) (i)

\title{
Changes in the aerosol direct radiative forcing from 2001 to 2015: observational constraints and regional mechanisms
}

\author{
Fabien Paulot ${ }^{1,2}$, David Paynter ${ }^{1}$, Paul Ginoux ${ }^{1}$, Vaishali Naik ${ }^{1}$, and Larry W. Horowitz ${ }^{1}$ \\ ${ }^{1}$ Geophysical Fluid Dynamics Laboratory, National Oceanic and Atmospheric Administration, Princeton, New Jersey, USA \\ ${ }^{2}$ Program in Atmospheric and Oceanic Sciences, Princeton University, Princeton, New Jersey, USA
}

Correspondence: Fabien Paulot (fabien.paulot@noaa.gov)

Received: 6 February 2018 - Discussion started: 13 February 2018

Revised: 30 August 2018 - Accepted: 31 August 2018 - Published: 14 September 2018

\begin{abstract}
We present estimates of changes in the direct aerosol effects (DRE) and its anthropogenic component (DRF) from 2001 to 2015 using the GFDL chemistryclimate model AM3 driven by CMIP6 historical emissions. AM3 is evaluated against observed changes in the clear-sky shortwave direct aerosol effect $\left(\mathrm{DRE}_{\mathrm{sw}}^{\mathrm{clr}}\right)$ derived from the Clouds and the Earth's Radiant Energy System (CERES) over polluted regions. From 2001 to 2015, observations suggest that $\mathrm{DRE}_{\mathrm{clr}}^{\mathrm{sw}}$ increases (i.e., less radiation is scattered to space by aerosols) over western Europe $\left(0.7-1 \mathrm{~W} \mathrm{~m}^{-2} \mathrm{decade}^{-1}\right)$ and the eastern US $\left(0.9-1.4 \mathrm{~W} \mathrm{~m}^{-2} \mathrm{decade}^{-1}\right)$, decreases over India $(-1$ to $-1.6 \mathrm{~W} \mathrm{~m}^{-2}$ decade $^{-1}$ ), and does not change significantly over eastern China. AM3 captures these observed regional changes in DRE $E_{\text {clr }}^{\mathrm{sw}}$ well in the US and western Europe, where they are dominated by the decline of sulfate aerosols, but not in Asia, where the model overestimates the decrease of $\mathrm{DRE}_{\mathrm{clr}}^{\mathrm{sw}}$. Over India, the model bias can be partly attributed to a decrease of the dust optical depth, which is not captured by our model and offsets some of the increase of anthropogenic aerosols. Over China, we find that the decline of $\mathrm{SO}_{2}$ emissions after 2007 is not represented in the CMIP6 emission inventory. Accounting for this decline, using the Modular Emission Inventory for China, and for the heterogeneous oxidation of $\mathrm{SO}_{2}$ significantly reduces the model bias. For both India and China, our simulations indicate that nitrate and black carbon contribute more to changes in $\mathrm{DRE}_{\mathrm{clr}}^{\mathrm{sw}}$ than in the US and Europe. Indeed, our model suggests that black carbon $\left(+0.12 \mathrm{~W} \mathrm{~m}^{-2}\right)$ dominates the relatively weak change in DRF from 2001 to $2015\left(+0.03 \mathrm{~W} \mathrm{~m}^{-2}\right)$. Over this period, the changes in the forcing from nitrate and sulfate are both small and of the same magnitude $\left(-0.03 \mathrm{~W} \mathrm{~m}^{-2}\right.$ each).
\end{abstract}

This is in sharp contrast to the forcing from 1850 to 2001 in which forcings by sulfate and black carbon largely cancel each other out, with minor contributions from nitrate. The differences between these time periods can be well understood from changes in emissions alone for black carbon but not for nitrate and sulfate; this reflects non-linear changes in the photochemical production of nitrate and sulfate associated with changes in both the magnitude and spatial distribution of anthropogenic emissions.

\section{Introduction}

Aerosols affect climate (Boucher et al., 2013) both directly, via scattering and absorption of solar and terrestrial radiation (Charlson et al., 1992), and indirectly, by modulating the abundance of cloud condensation nuclei, the droplet size distribution, and the lifetime of clouds (Twomey, 1974; Rosenfeld et al., 2014). Storelvmo et al. (2016) estimated that the increase in the burden of atmospheric aerosols associated with anthropogenic activities has masked approximately onethird of the continental warming from greenhouse gases from 1964 to 2010, with important implications for global and regional climate (Wild, 2009; Bollasina et al., 2011).

Previous studies have leveraged global spaceborne observations of the Earth's radiative budget (Wielicki et al., 1996, 1998) and aerosol abundance (Kahn et al., 2005; R. C. Levy et al., 2013) to estimate the overall aerosol direct radiative effect (DRE), i.e., the direct perturbation of the Earth's radiative budget by aerosols (Christopher and Zhang, 2004; Patadia et al., 2008; Loeb and Manalo-Smith, 2005; Kahn, 2012). Observational constraints for the aerosol direct ra- 
diative forcing (DRF), the anthropogenic component of the aerosol direct radiative effect, are less robust (Su et al., 2013; Bellouin et al., 2005, 2008), which contributes to the large spread in model estimates for DRF in 2000 relative to 1850 ( -0.02 to $-0.58 \mathrm{~W} \mathrm{~m}^{-2}$; Myhre et al., 2013). In particular, the sensitivity of the aerosol direct radiative forcing to anthropogenic emissions remains uncertain. Previous work has shown that the aerosol forcing simulated by global climate models from 1850 to 2001 is well correlated with changes in $\mathrm{SO}_{2}$ emissions (Stevens, 2015). However, this relationship may not be applicable in recent years and for future conditions, as the spatial distribution and speciation of anthropogenic emissions evolve (Stevens et al., 2017).

In this work, we aim to provide observational constraints on the sensitivity of the direct aerosol forcing to anthropogenic emissions. The paper is organized as follows: first, we derive an estimate of changes in the clear-sky shortwave aerosol direct radiative effect from 2001 to 2015 constrained by the observed variability in outgoing shortwave radiation from the Clouds and the Earth's Radiant Energy System (CERES). Second, we focus on large source regions of anthropogenic emissions (the eastern US, western Europe, India, and eastern China), where observed changes in the aerosol effect are expected to be dominated by anthropogenic aerosols. This allows us to assess whether a state-ofthe-art chemistry-climate model (Geophysical Fluid Dynamics Laboratory (GFDL) AM3) driven by the latest emissions from the Coupled Model Intercomparison Project Phase 6 (CMIP6) can capture changes in the direct radiative forcing from aerosols over the 2001-2015 period. Finally we use AM3 to compare the sensitivity of the aerosol direct radiative forcing to anthropogenic emissions from 1850 to 2001 and from 2001 to 2015.

\section{Methods}

\subsection{GFDL AM3 model}

We use the GFDL AM3 model (Donner et al., 2011; Naik et al., 2013), the atmospheric chemistry climate component of the GFDL-CM3 model (Donner et al., 2011; Griffies et al., 2011; John et al., 2012). The model is run from 2000 to 2015, using the first year to spin up the model. The model horizontal resolution is $\simeq 200 \mathrm{~km}$ with 48 vertical levels. To facilitate comparisons with synoptic observations, the model horizontal winds are nudged to 6-hourly horizontal winds from the National Centers for Environmental Predication reanalysis (Kalnay et al., 1996). Monthly sea surface temperature and sea ice concentration are prescribed following Taylor et al. (2000) and Rayner et al. (2003), respectively. The configuration of AM3 used in this study includes revisions to the representation of the wet scavenging of chemical tracers by snow and convective precipitation and to the treatment of sulfate and nitrate chemistry, which significantly improve the repre- sentation of aerosols. We refer the reader to our recent work for a detailed evaluation of the aerosol simulation in AM3 (Paulot et al., 2016).

The radiative transfer scheme takes the aerosol optical properties of sulfate, sea salt, dust, black carbon BC, organic carbon (Donner et al., 2011) and nitrate (Paulot et al., 2017b) into account. Aerosols are assumed to be externally mixed, except for hydrophilic black carbon and sulfate (Donner et al., 2011). Hygroscopic growth is capped at $95 \%$ for all aerosols.

We use the historical anthropogenic emissions developed by the Community Emission Data System (CEDS v2017-0518) in support of CMIP6 (Hoesly et al., 2018). As anthropogenic emissions are only available until 2014 from CEDS, we repeat CEDS 2014 anthropogenic emissions for 2015. Monthly biomass burning emissions are from the historical global biomass burning emissions inventory for CMIP6 (BB4CMIP6; van Marle et al., 2017). Emissions for the 1997 to 2015 period in this inventory have been derived from satellite-based emissions from the Global Fire Emissions Database (GFED; van der Werf et al., 2017). The vertical distribution of biomass burning emissions is taken from Dentener et al. (2006). Natural emissions are based on Naik et al. (2013), except for isoprene emissions, which are calculated interactively using the Model of Emissions of Gases and Aerosols from Nature (MEGAN; Guenther et al., 2006).

Figure 1 shows changes in the anthropogenic emissions of sulfur dioxide $\left(\mathrm{SO}_{2}\right)$, ammonia $\left(\mathrm{NH}_{3}\right)$, black carbon $(\mathrm{BC})$, and nitrogen oxide (NO) from 2001 to 2015. Globally, anthropogenic emissions of $\mathrm{NH}_{3}, \mathrm{BC}$, and $\mathrm{NO}$ have increased by $18 \%, 36 \%$, and $16 \%$ over the $2001-2015$ period, respectively, while $\mathrm{SO}_{2}$ emissions have remained almost stable, peaking in 2006. In the US and Europe, there have been significant declines in $\mathrm{SO}_{2}(-71 \%$ and $-66 \%$, respectively) and $\mathrm{NO}(-48 \%$ and $-39 \%$, respectively) emissions, while $\mathrm{NH}_{3}$ and $\mathrm{BC}$ emissions have changed little $(<15 \%)$. Indian emissions of $\mathrm{SO}_{2}, \mathrm{NO}$, and $\mathrm{BC}$ have increased by $89 \%$, $39 \%$, and $89 \%$, respectively. Similarly, Chinese emissions of $\mathrm{SO}_{2}, \mathrm{NO}$, and $\mathrm{BC}$ have increased by $56 \%, 69 \%$, and $93 \%$, respectively. Anthropogenic emissions in India and China are expected to be more uncertain than in the US and Europe (Saikawa et al., 2017a, b). For instance, Fig. 1 shows differences between emissions from CMIP6 and emissions from the regional Multi-resolution Emission Inventory for China (MEIC) (Zhang et al., 2009). Unlike in CMIP6, emissions of $\mathrm{SO}_{2}$ in MEIC decline starting in 2006, a decrease that accelerates in 2012, while NO emissions decrease after 2012 and BC emissions remain near-stable after 2007. In 2014, MEIC NO, $\mathrm{SO}_{2}$, and $\mathrm{BC}$ emissions are $24 \%, 48 \%$, and $32 \%$ lower than CMIP6 emissions, respectively. $\mathrm{NH}_{3}$ emissions are similar in magnitude but exhibit different seasonality: CMIP6 $\mathrm{NH}_{3}$ emissions peak in spring, while MEIC exhibits a broad peak in summer, consistent with top-down constraints (Paulot et al., 2014; Zhang et al., 2018). The impact of these emission uncertainties on the simulated change 

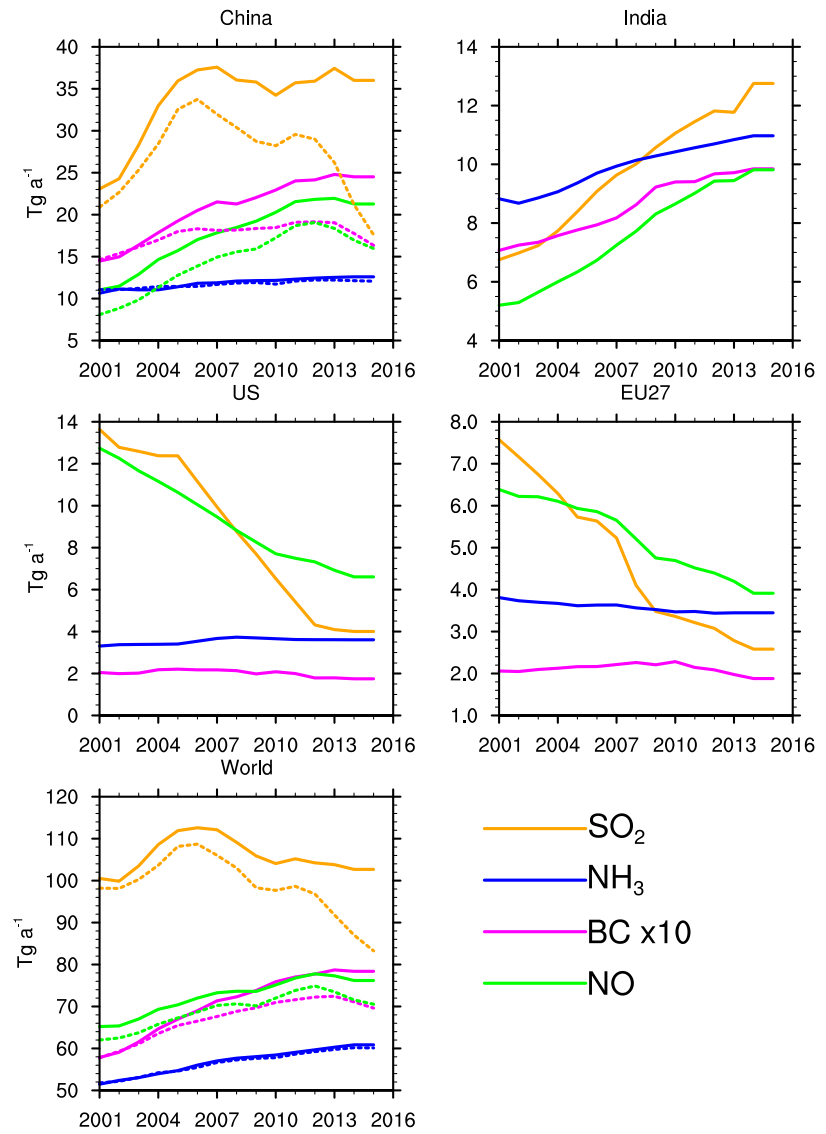

Figure 1. Annual anthropogenic emissions of $\mathrm{SO}_{2}, \mathrm{BC}, \mathrm{NH}_{3}$, and NO from CMIP6 (solid lines) in selected regions. Anthropogenic emissions estimated by replacing CMIP6 with MEIC over China are also shown (dashed lines).

in the aerosol effect over India and China will be discussed in Sect. 3.2.2 and 3.2.3, respectively.

\subsection{Aerosol direct effect and forcing}

The instantaneous aerosol direct radiative effect (DRE) is defined as the difference between the outgoing radiation at the top of the atmosphere (TOA) in the absence and in the presence of aerosols (Heald et al., 2014). The direct radiative forcing (DRF) is defined as the anthropogenic component of the direct radiative effect. In our notation we use the superscript sw to denote the shortwave component of DRE or DRF. Likewise, the subscript clr denotes the clear-sky component of DRE or DRF.

To better isolate the effect of aerosol variability on radiative fluxes, we will focus on the aerosol shortwave direct radiative effect under clear-sky conditions (DRE $\left.E_{\mathrm{clr}}^{\mathrm{sw}}\right)$ :

$\mathrm{DRE}_{\mathrm{clr}}^{\mathrm{sw}}=$ rsutcsaf - rsutcs,

where we use the CMIP6 convention (CMIP6 Data Request, 2017) to designate the outgoing clear-sky shortwave radia- tion with (rsutcs: radiation shortwave up TOA clear sky) and without aerosols (rsutcsaf: radiation shortwave up TOA clear sky aerosol free), respectively. For simplicity, we will refer to the aerosol shortwave direct radiative effect under clear-sky conditions $\left(\mathrm{DRE}_{\mathrm{clr}}^{\mathrm{sw}}\right)$ as the aerosol effect, hereafter. Note that an increase of the aerosol direct effect indicates a decrease of the radiation scattered to space by aerosols.

\subsubsection{Model}

In AM3, the aerosol effect is estimated by calling the radiative transfer scheme twice, with and without aerosols (Paulot et al., 2017b) in the absence of clouds. The effect of individual aerosol components is estimated as the difference in outgoing shortwave radiation with and without aerosol $x$, where $x$ can be sulfate, nitrate, black carbon, organic carbon, dust, sea salt, or stratospheric volcanic aerosols. In the following, we will focus primarily on changes in sulfate and nitrate, which dominate changes in aerosol scattering, and black carbon, which dominates changes in aerosol absorption over the 2001-2015 period.

\subsubsection{Observations}

The Clouds and the Earth's Radiant Energy System (CERES; Wielicki et al., 1996, 1998) provides constraints on the Earth's radiative budget since 2000. Here, we use the Energy Balanced and Filled product (EBAF, edition 4; Loeb et al., 2018) to estimate the variability of the clear-sky shortwave outgoing radiation. This product achieves global coverage by combining CERES broadband cloud-free fluxes with MODIS (Moderate Resolution Imaging Spectroradiometer) radiances for regions that are not completely cloud-free at the CERES footprint scale (Loeb et al., 2018).

The simplest way in which CERES EBAF data can be used to estimate changes in the aerosol effect is to assume that all variability in the shortwave clear-sky outgoing radiation is the result of changes in aerosols (Stevens and Schwartz, 2012; Xing et al., 2015; Alfaro-Contreras et al., 2017). We will refer to this estimate as $\mathrm{EBAF}_{\mathrm{R}}$ hereafter, where the subscript R stands for raw. However, other radiative components may contribute to the variability in the outgoing radiation (Stevens and Schwartz, 2012). Therefore, a more accurate estimate of the aerosol effect requires the removal of the impact of these components from the measured changes in the outgoing radiation. To achieve this, we calculate radiative kernels (e.g., Soden et al., 2008; Shell et al., 2008) to estimate the variability of the outgoing clear-sky shortwave radiation associated with changes in surface albedo, ozone, and water vapor (see Supplement and Fig. S1). For water vapor and ozone, we use the Goddard Modeling and Assimilation Office reanalysis (GEOS-5). Since our estimate for the aerosol effect is most sensitive to changes in the surface albedo, we will consider both the albedo from MODIS (Schaaf et al., 2002) and CERES EBAF (Rutan et al., 2009, 2015; Loeb 
et al., 2018). Both albedo estimates have been validated extensively and generally show good agreement with observations (Cescatti et al., 2012; Z. Wang et al., 2014; Rutan et al., 2009, 2015). Estimates of the aerosol effect derived using the MODIS and CERES EBAF albedo will be referred to as $\mathrm{EBAF}_{\mathrm{M}}$ and $\mathrm{EBAF}_{\mathrm{C}}$, respectively.

We also derive the change in the aerosol effect from the CERES Synoptic Radiative Fluxes product (SYN, edition 4a). Similar to AM3, the CERES SYN product provides estimates of the radiative fluxes at the top of the atmosphere with and without aerosols present. In the SYN product, the radiative transfer calculations use aerosol properties from the Model for Atmospheric Transport and Chemistry (MATCH), which is constrained by observations from MODIS Collection 5 (Collins et al., 2001). Therefore, the SYN calculated aerosol effect is very sensitive to MODIS Collection 5 aerosol properties. This collection has now been superseded by MODIS Collection 6 (R. C. Levy et al., 2013) and we will discuss some of the implications of differences between MODIS collections 5 and 6 for the derivation of the SYN aerosol effect in Sect. 3.2.1 and 3.2.2.

\subsection{Trend: estimation and interpretation}

We use the non-parametric Mann-Kendall test (Kendall, 1938) to identify significant changes in the aerosol effect. This test quantifies monotonic correlations between two variables. It is based on a rank procedure that makes it less susceptible to outliers than the Pearson correlation; thus, it is especially well-suited for the analysis of an environmental dataset. We estimate the linear trend using the Theil-Sen method (Theil, 1950; Sen, 1968). We use a critical $p$ value of 0.05 for trend significance.

Differences between observed and simulated trends in $D R E_{\text {clr }}^{\mathrm{sw}}$ may reflect biases in the simulated change of the aerosol burden. Here this is diagnosed by comparing the simulated trend in aerosol optical depth (AOD) with those retrieved by the Multi-angle Imaging Spectroradiometer (MISR) at $555 \mathrm{~nm}$ (Kahn et al., 2005, 2010) and the MODIS instruments on board the Aqua and Terra satellites at $550 \mathrm{~nm}$ (Collection 6, Level 3, merged deep blue/dark target) (H. Levy et al., 2013; Sayer et al., 2014). Note that the accuracy of individual retrievals has been estimated to be $\pm 0.05 \pm 0.15 \times$ AOD (Levy et al., 2010) for MODIS and a maximum of \pm 0.05 or $0.2 \times$ AOD for MISR (Kahn et al., 2010).

The change in AOD is not a perfect predictor of changes in $\mathrm{DRE}_{\mathrm{sw}}^{\mathrm{clr}}$ and we will show that it is possible to find regions where observed changes in AOD are well captured by AM3 but not changes in $D_{R E}^{\text {clr }}$ (see Sect. 3.2.2). Such discrepancies may reflect differences in aerosol radiative properties. Specifically, changes in absorbing aerosols, such as black carbon, have a small imprint on AOD but a large one on $\mathrm{DRE}_{\mathrm{clr}}^{\mathrm{sw}}$ (see Sect. 3.2.2 and 3.2.3). Differences in surface properties may also cause differences in $\mathrm{DRE}_{\text {clr }}^{\mathrm{sw}}$ trends. For instance, a lower surface albedo reduces the impact of changes in scattering aerosols on $\mathrm{DRE}_{\mathrm{sw}}^{\mathrm{clr}}$ and conversely increases that of absorbing aerosols. We will show that such differences in surface albedo are important in India (Sect. 3.2.2). However, in other regions, we find they have a small impact on the simulated trend in $\mathrm{DRE}_{\mathrm{sw}}^{\mathrm{clr}}$.

\section{Results}

In this section, we will refer to the clear-sky shortwave outgoing radiation (rsutcs) and the aerosol shortwave direct radiative effect under clear-sky conditions (DRE $\mathrm{clr}^{\mathrm{sw}}$ ) as outgoing radiation and aerosol effect, respectively.

\subsection{Global distribution of changes in aerosol effect}

Figure 2 shows the decadal rate of change in the aerosol effect, estimated solely from changes in the outgoing radiation $\left(\mathrm{EBAF}_{\mathrm{R}}\right)$ measured by CERES EBAF (top panel) over the 2001-2015 period. We find significant changes (highlighted with dots) in the outflow of the eastern US, where the radiation scattered back to space by aerosols decreases, and in the outflow of India, where it increases, consistent with the changes in anthropogenic emissions shown in Fig. 1. However, changes in the outgoing radiation are less significant over the source regions themselves, which highlights the importance of other factors of variability in the outgoing radiation (Stevens and Schwartz, 2012).

Figure 2 also shows the decadal rate of change in the aerosol effect derived from the SYN calculation and from CERES EBAF outgoing radiation after correction for water, ozone, and surface albedo from MODIS $\left(\mathrm{EBAF}_{\mathrm{M}}\right)$ and CERES EBAF $\left(\mathrm{EBAF}_{\mathrm{C}}\right)$. All of these estimates show better spatial consistency between land and ocean near large sources of anthropogenic pollution than the outgoing radiation alone $\left(\mathrm{EBAF}_{\mathrm{R}}\right)$. In particular, we find that the aerosol effect increases over North America and Europe, and decreases over India. In contrast, the variability is considerably reduced over Australia, central Asia, and South America, which suggests that it is not primarily associated with aerosols. Consistent with observations, AM3 also shows that the aerosol effect increases over the US and Europe and decreases over India. However, it simulates a decrease in the aerosol effect over China and in the western Pacific, which is inconsistent with observational constraints.

To understand these changes further, we examine the time series of the different estimates of the aerosol effect over these regions. $\mathrm{EBAF}_{\mathrm{R}}$ exhibits considerable interannual variability over the eastern US and Europe, with no significant trend (Table S1). In contrast, SYN, $\mathrm{EBAF}_{\mathrm{C}}$, and $\mathrm{EBAF}_{\mathrm{M}}$ estimates exhibit a significant increase ranging from 0.9 to $1.8 \mathrm{~W} \mathrm{~m}^{-2} \mathrm{decade}^{-1}$ in the eastern US and from 0.7 to $1.4 \mathrm{~W} \mathrm{~m}^{-2}$ decade $^{-1}$ in western Europe. AM3 also simulates an increase of the aerosol effect over these regions ( 0.8 and 


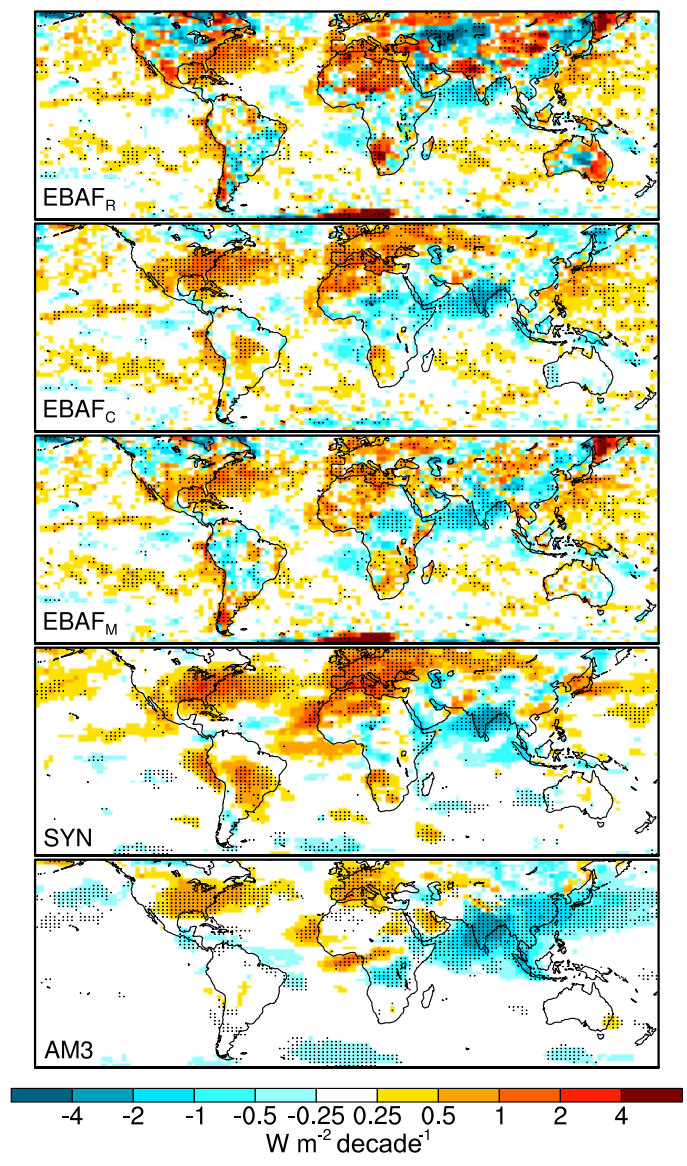

Figure 2. Rate of change in the clear-sky shortwave aerosol direct radiative effect $\left(D_{R E} E_{c l r}^{\mathrm{sw}}\right)$. An increase in $\mathrm{DRE}_{\mathrm{clr}}^{\mathrm{sw}}$ reflects a decrease in the amount of radiation scattered to space by aerosols. $\mathrm{EBAF}_{\mathrm{R}}$ is based on the outgoing clear-sky shortwave radiation from CERES EBAF assuming its variability is solely associated with aerosols. $\mathrm{EBAF}_{\mathrm{C}}$ and $\mathrm{EBAF}_{\mathrm{M}}$ are estimated using the observed clear-sky outgoing shortwave fluxes from CERES EBAF after accounting for the variability of water vapor, ozone, and surface albedo from CERES EBAF and MODIS, respectively. Estimates from SYN (calculation constrained by observations) and from the GFDL AM3 global chemistry-climate model are also shown. Dotted areas are significant at the $95 \%$ confidence level.

$0.6 \mathrm{~W} \mathrm{~m}^{-2}$ decade $^{-1}$, respectively). The magnitude of these changes is in excellent agreement with $\mathrm{EBAF}_{\mathrm{M}}$ but lower than SYN. We refer the reader to Sect. 3.2.1 for a detailed discussion of these regions.

Over India, most observational estimates $\left(\mathrm{SYN}, \mathrm{EBAF}_{\mathrm{C}}\right.$, EBAF $\left._{M}\right)$ suggest a decrease of the aerosol effect $(-1.0$ to $-1.9 \mathrm{~W} \mathrm{~m}^{-2}$ decade $^{-1}$ ), which is qualitatively captured by AM3 $\left(-2.4 \mathrm{~W} \mathrm{~m}^{-2} \mathrm{decade}^{-1}\right)$. However, changes in the outgoing radiation alone $\left(\mathrm{EBAF}_{\mathrm{R}}\right)$ would imply a small increase of the aerosol effect from 2001 to 2015 $\left(0.5 \mathrm{~W} \mathrm{~m}^{-2} \mathrm{decade}^{-1}\right)$, which suggests that large changes in other radiative components may be masking the aerosol ef- fect. Changes in the aerosol effect over India will be discussed in Sect. 3.2.2.

Over eastern China, all observational estimates of the aerosol effect exhibit a rapid decrease from 2001 to 2007, followed by an increase until 2015, with no significant trend overall in $\mathrm{SYN}, \mathrm{EBAF}_{\mathrm{C}}$, and $\mathrm{EBAF}_{\mathrm{M}}$. The timing of the reversal is consistent with previous analyses of changes in AOD (Zhao et al., 2017) and outgoing radiation in the outflow of China (Alfaro-Contreras et al., 2017). AM3 fails to capture this reversal and simulates a significant decrease in the aerosol effect from 2001 to 2015 $\left(-1.3 \mathrm{~W} \mathrm{~m}^{-2}\right.$ decade $\left.^{-1}\right)$. Changes in the aerosol effect over China will be discussed in Sect. 3.2.3.

We note that all observation-based estimates of DRE show some significant changes over remote oceanic regions. These changes may reflect cloud contaminations in the CERES cloud filtering algorithm (for $\mathrm{EBAF}_{\mathrm{C}}, \mathrm{EBAF}_{\mathrm{M}}$ ) and in the aerosol retrieval (SYN). In addition, low aerosol loadings make $\mathrm{EBAF}_{\mathrm{C}}$ and $\mathrm{EBAF}_{\mathrm{M}}$ more susceptible to errors in the radiative kernels.

\subsection{Regional changes}

\subsubsection{Western Europe and eastern US}

Figure 4 (top row) shows the seasonal change of the AOD and the aerosol effect over Europe. Observations show that the AOD decreases most in spring and summer $\left(-0.4 \mathrm{decade}^{-1}\right.$ for MODIS Terra - solid black line, Table 1). This decrease is accompanied by an increase of the aerosol effect of $1-1.8 \mathrm{~W} \mathrm{~m}^{-2}$ decade $^{-1}$ in spring and 1.2 $2.5 \mathrm{~W} \mathrm{~m}^{-2}$ decade $^{-1}$ in summer (Fig. 4 , bottom row and Table 1). AM3 captures these changes well (Table S2). In the model, both changes in AOD and the aerosol effect are driven almost entirely by the decrease of sulfate aerosols associated with the decrease of $\mathrm{SO}_{2}$ emissions. The slower changes in winter and fall reflect the smaller contribution of sulfate to the aerosol burden and the less efficient oxidation of $\mathrm{SO}_{2}$ in these seasons, which makes sulfate less sensitive to changes in $\mathrm{SO}_{2}$ emissions (Wang et al., 2011; Paulot et al., 2017a).

Figure 5 shows the changes of the AOD and the aerosol effect over the eastern US. The overall pattern is similar to western Europe with large reductions in AOD (up to -0.11 decade $^{-1}$ ) and increases in the aerosol effect (up to $3.6 \mathrm{~W} \mathrm{~m}^{-2}$ decade $^{-1}$ ) in spring and summer (Table 1). AM3 underestimates MODIS AOD as well as the rate of change of the AOD and the aerosol effect in summer (Table 1). This is consistent with the model's low bias against the sulfate concentration in rain water in the US (Paulot et al., 2016). Similar to observations, AM3 also shows greater seasonal contrast between spring and summer in the US than in Europe. In the model, this is driven by more efficient springtime oxidation of $\mathrm{SO}_{2}$ in Europe, where high emissions of ammonia facilitate its in-cloud oxidation by ozone (Paulot et al., 2017a). 


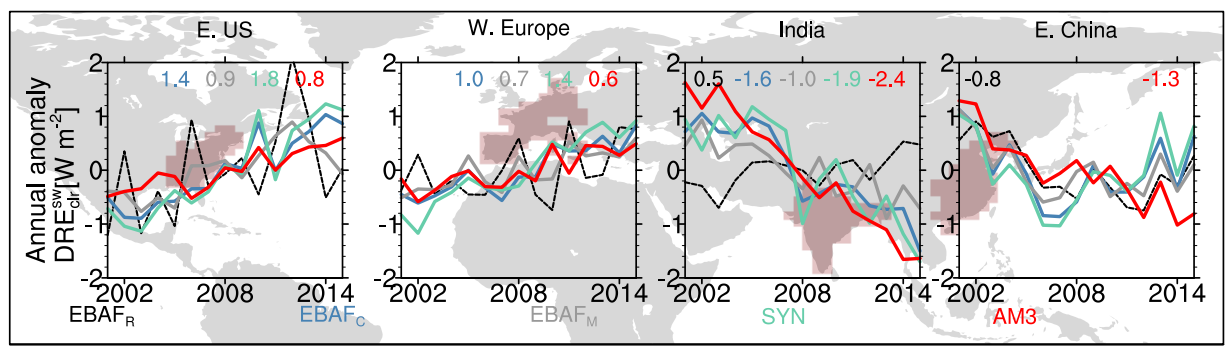

Figure 3. Regional changes in the clear-sky shortwave aerosol direct radiative effect derived from CERES EBAF outgoing radiation without correction $\left(\mathrm{EBAF}_{\mathrm{R}}\right.$, black) and after correcting for the variability of water, ozone, and surface albedo (from CERES EBAF, EBAF $\mathrm{C}_{\mathrm{C}}$, blue; or from MODIS, EBAF $\mathrm{M}_{\mathrm{M}}$, grey) over the eastern US, western Europe, India, and eastern China. Estimates from SYN (calculation constrained by observations) and from the GFDL AM3 global chemistry-climate model are shown in green and red, respectively. The rate of change for each estimate is indicated in $\mathrm{W} \mathrm{m}^{-2}$ decade $^{-1}$ when significant $(p<0.05)$.
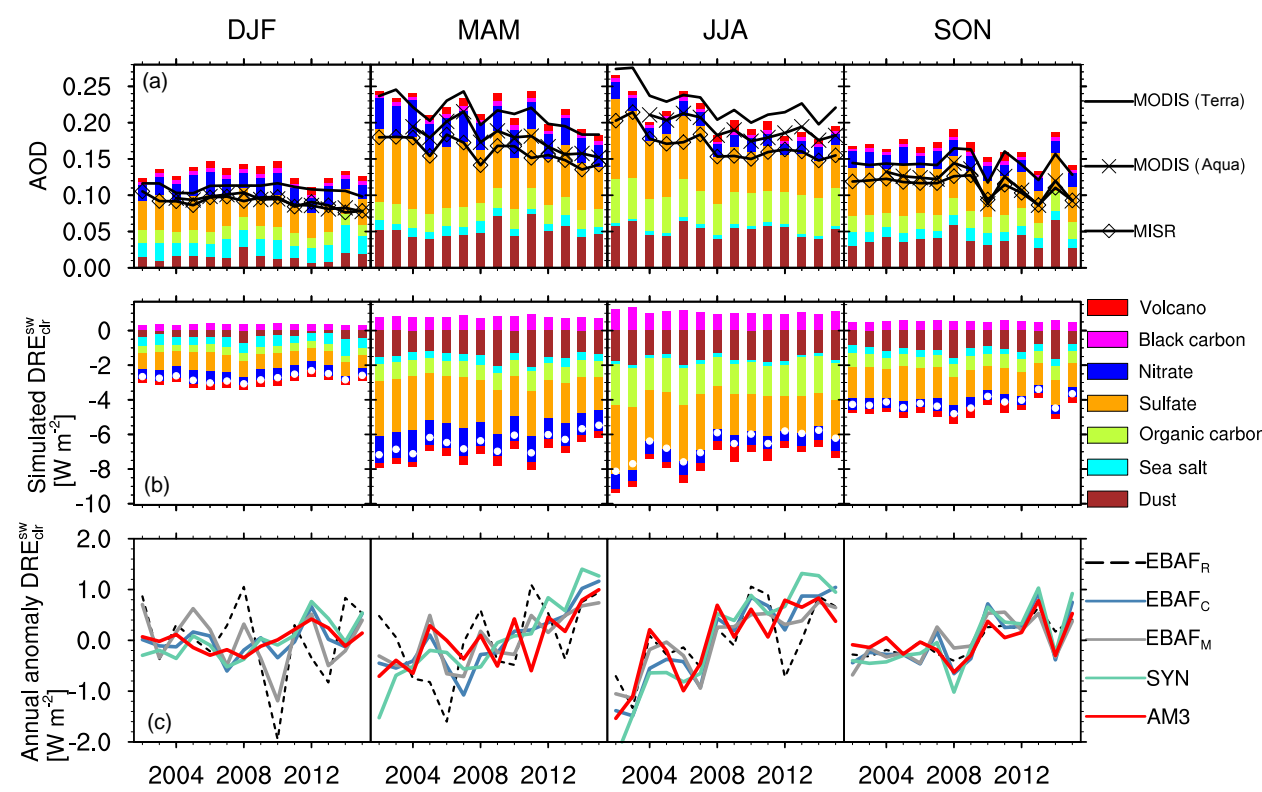

Figure 4. Seasonal changes in the aerosol optical depth (AOD) and clear-sky shortwave aerosol direct radiative effect (DRE clr $)$ in western Europe (Fig. 3). The top row (a) shows the AOD retrieved from different spaceborne instruments (MODIS-Terra - lines, MODIS-Aqua crosses, MISR - diamonds) and the simulated AOD decomposed into its components (bars). The second row (b) shows the simulated clearsky shortwave aerosol direct radiative effect of individual aerosols (bars) and the overall aerosol direct radiative effect (white circles). The bottom row (c) shows observation-based and simulated estimates of changes in the aerosol direct radiative effect.

In both Europe and the US, we find that the change in the aerosol effect inferred from the SYN calculation is larger than that estimated from CERES EBAF outgoing radiation corrected for surface albedo changes $\left(\mathrm{EBAF}_{\mathrm{C}}\right.$ and $\left.\mathrm{EBAF}_{\mathrm{M}}\right)$. The magnitude of the changes in the MATCH AOD, which is based on MODIS Collection 5 and used to calculated the SYN aerosol effect, is also greater than that inferred from the improved MODIS Collection 6 (Table 1). This suggests that the rate of change in the SYN aerosol effect may be biased high in western Europe and the eastern US.

\subsubsection{India}

Figure 6 shows the changes in the AOD and the aerosol effect over India. We will focus here on changes during the winter (DJF) and pre-monsoon seasons (MAM).

Previous studies have shown that aerosols are primarily of anthropogenic origin in winter (Babu et al., 2013; Pan et al., 2015). During this season, all instruments show a significant increase in AOD (up to 0.13 decade $^{-1}$ ). In spite of this increase, the outgoing radiation $\left(\mathrm{EBAF}_{\mathrm{R}}\right)$ does not exhibit a significant trend. We attribute this apparent inconsistency to a concurrent decrease in surface albedo (Table S3), which may be associated with the increase in the regional greenness 
Table 1. Trends in the aerosol optical depth $\left(\mathrm{AOD}\right.$, decade $\left.^{-1}\right)$, and the direct clear-sky shortwave radiative effect $\left(\mathrm{DRE}_{\mathrm{clr}}^{\mathrm{sw}}, \mathrm{W} \mathrm{m}^{-2} \mathrm{decade}^{-1}\right)$ for selected regions and seasons from 2002 to $2015^{\mathrm{a}}$.

\begin{tabular}{|c|c|c|c|c|c|c|c|}
\hline & \multicolumn{2}{|c|}{ Western Europe } & \multicolumn{2}{|c|}{ Eastern US } & \multicolumn{2}{|c|}{ India } & \multirow{2}{*}{$\begin{array}{r}\text { Eastern China } \\
\text { MAM }\end{array}$} \\
\hline & MAM & JJA & MAM & JJA & DJF & MAM & \\
\hline \multicolumn{8}{|l|}{ AOD } \\
\hline MODIS (Terra) & $-0.04[0.21]$ & $-0.04[0.23]$ & $-0.04[0.20]$ & $-0.11[0.32]$ & $0.13[0.39]$ & $0.04[0.43]$ & $*[0.71]$ \\
\hline MODIS (Aqua) & $-0.05[0.18]$ & $-0.03[0.19]$ & $-0.04[0.16]$ & $-0.10[0.29]$ & $0.11[0.35]$ & $0.07[0.40]$ & $*[0.68]$ \\
\hline MISR & $-0.03[0.16]$ & $-0.03[0.17]$ & $-0.02[0.15]$ & $-0.08[0.22]$ & $0.05[0.29]$ & $*[0.39]$ & \\
\hline MATCH $^{b}$ & $-0.06[0.27]$ & $-0.06[0.26]$ & $-0.07[0.29]$ & $-0.11[0.35]$ & $0.10[0.36]$ & $0.03[0.49]$ & $*[0.90]$ \\
\hline AM3 & $-0.04[0.22]$ & $-0.05[0.21]$ & $-0.03[0.19]$ & $-0.05[0.23]$ & $0.13[0.33]$ & $0.15[0.47]$ & $0.15[0.70]$ \\
\hline Sulfate & $-0.03[0.08]$ & $-0.04[0.07]$ & $-0.03[0.09]$ & $-0.06[0.12]$ & $0.02[0.09]$ & $0.07[0.17]$ & $0.05[0.30]$ \\
\hline Nitrate & $-0.01[0.04]$ & $*[0.02]$ & $*[0.03]$ & $0.00[0.01]$ & $0.07[0.10]$ & $0.06[0.07]$ & $0.08[0.14]$ \\
\hline Black carbon & $*[0.01]$ & $*[0.00]$ & $*[0.01]$ & $*[0.00]$ & $0.01[0.02]$ & $0.01[0.02]$ & $0.01[0.04]$ \\
\hline \multicolumn{8}{|l|}{$\mathrm{DRE}_{\mathrm{clr}}^{\mathrm{sw}}$} \\
\hline SYN & $1.8[-8.9]$ & $2.5[-9.4]$ & $2.1[-8.6]$ & $3.6[-11.0]$ & $-2.6[-9.1]$ & $-1.4[-13.4]$ & $*[-20.5]$ \\
\hline $\mathrm{EBAF}_{\mathrm{C}}$ & 1.4 & 1.8 & 1.3 & 3.3 & -2.3 & -1.2 & $*$ \\
\hline $\mathrm{EBAF}_{\mathrm{M}}$ & 1.0 & 1.2 & $*$ & 2.0 & -0.8 & -0.9 & $*$ \\
\hline AM3 & $1.1[-6.5]$ & $1.5[-6.6]$ & $0.9[-5.3]$ & $1.4[-6.9]$ & $-2.7[-6.6]$ & $-3.1[-9.4]$ & $-2.1[-13.9]$ \\
\hline Sulfate & $0.9[-2.6]$ & $1.5[-2.7]$ & $1.1[-3.1]$ & $2.2[-3.9]$ & $-0.7[-2.9]$ & $-1.8[-5.5]$ & $-1.1[-8.5]$ \\
\hline Nitrate & $0.3[-1.4]$ & $*[-0.7]$ & $*[-1.2]$ & $-0.2[-0.2]$ & $-2.4[-3.3]$ & $-1.9[-2.6]$ & $-2.2[-4.2]$ \\
\hline Black carbon & $*[0.8]$ & $-0.2[1.1]$ & * [1.0] & $*[1.1]$ & $0.9[3.2]$ & $1.2[4.3]$ & $1.4[4.7]$ \\
\hline
\end{tabular}

a The average over the 2002-2015 period is shown in brackets (2003-2015 for Aqua). Trends are estimated using the Theil-Sen method. $*$ denotes non-significant monotonous change at $p=0.05$. Model AOD is sampled based on MODIS (Terra) seasonal coverage. No statistics are provided for China from MISR due to large differences in spatial coverage with MODIS (Terra). SYN refers to the aerosol effect calculated in the CERES SYN product. EBAF $\mathrm{C}_{\mathrm{C}}$ and $\mathrm{EBAF}_{\mathrm{M}}$ refer to the aerosol effect estimated using CERES EBAF outgoing shortwave clear-sky radiation corrected for the variability in water, ozone, and CERES EBAF (EBAF E $_{\text {) }}$ and MODIS (EBAF M $_{M}$ ) surface albedo.

Confidence intervals for the trends are provided in Table S2. ${ }^{b}$ From CERES SYN Ed4 based on assimilation of MODIS Collection 5 AOD with the MATCH model.

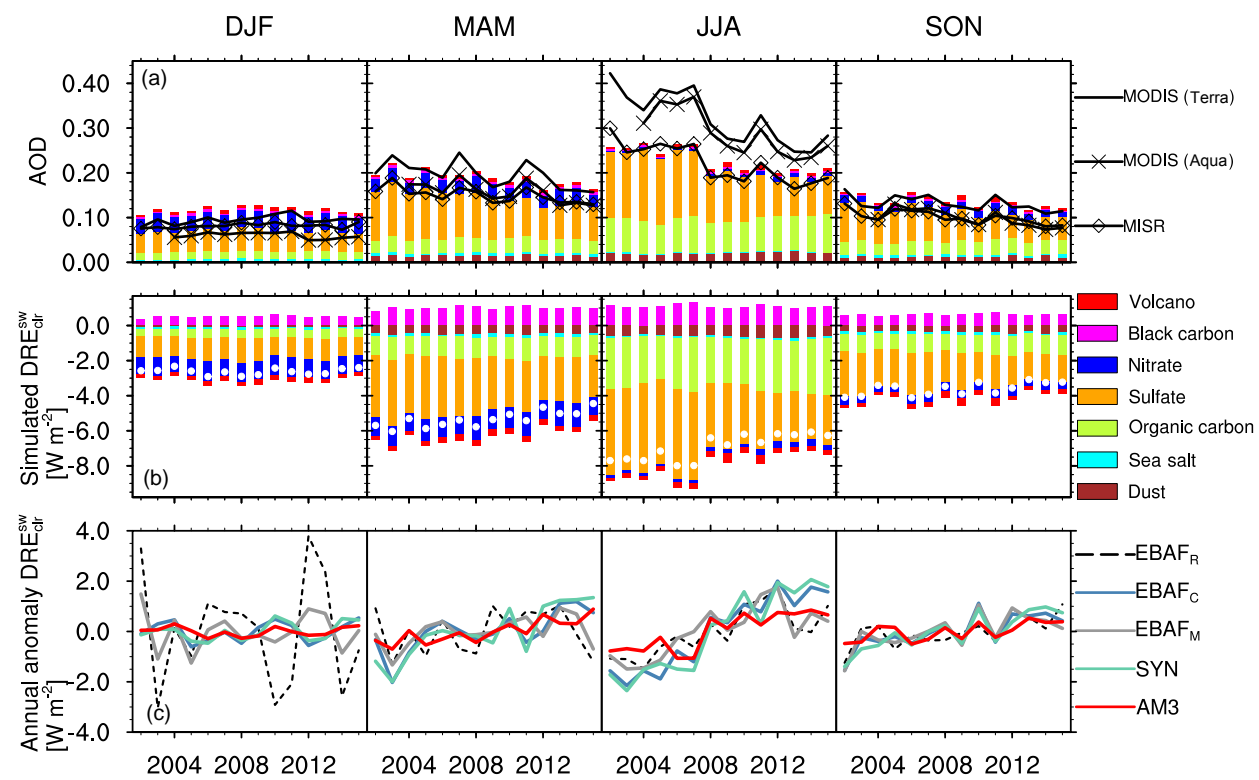

Figure 5. Same as Fig. 4 but for the eastern US.

leaf area index (LAI) reported by Zhu et al. (2016). Accounting for changes in surface albedo, we diagnose a decrease in the aerosol effect ranging from $-0.8 \mathrm{~W} \mathrm{~m}^{-2} \mathrm{decade}^{-1}$ (using MODIS albedo, EBAF ${ }_{M}$ ) to $-2.3 \mathrm{~W} \mathrm{~m}^{-2}$ decade $^{-1}$ (using CERES EBAF albedo, EBAF $_{\mathrm{C}}$ ). The large difference be- tween $\mathrm{EBAF}_{\mathrm{C}}$ and $\mathrm{EBAF}_{\mathrm{M}}$ reflects the difference between MODIS and CERES EBAF albedo in this region (Table S3).

Figure 6 shows that the simulated AOD agrees well for both magnitude and trend with MODIS AOD but overestimates the change in MISR AOD (see Table 1). The sim- 

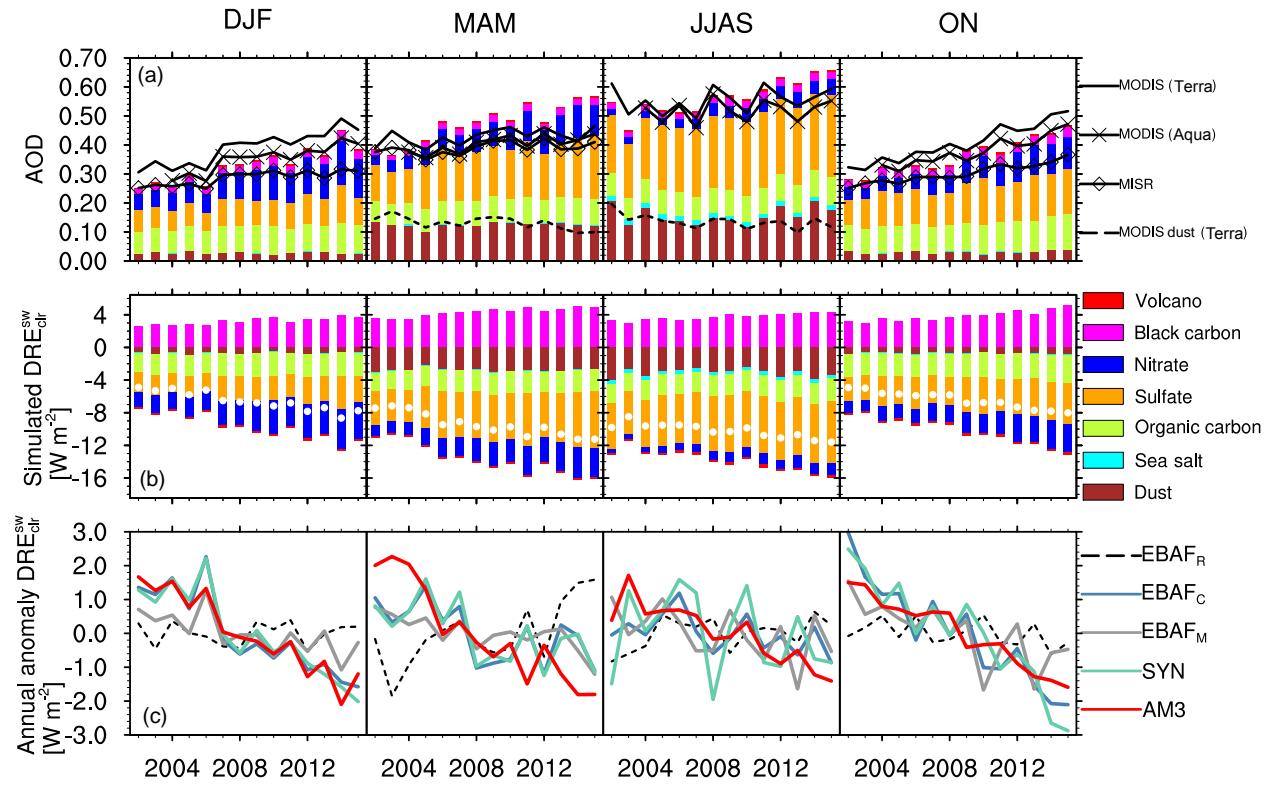

Figure 6. Same as Fig. 4 but for India. MISR is excluded in the monsoon season (JJAS), when its coverage is too sparse relative to MODIS (Terra). The MODIS-derived dust optical depth is indicated by a black dashed line.

ulated change in the aerosol effect $\left(-2.7 \mathrm{~W} \mathrm{~m}^{-2}\right.$ decade $\left.^{-1}\right)$ agrees well with the $\mathrm{EBAF}_{\mathrm{C}}$ and $\mathrm{SYN}$ estimates $(-2.3$ and $-2.6 \mathrm{~W} \mathrm{~m}^{-2} \mathrm{decade}^{-1}$, respectively). However, this good agreement is fortuitous, as the higher surface albedo in AM3 (0.166) relative to SYN (0.129) or CERESEBAF (0.135) tends to dampen changes in the simulated aerosol scattering. Specifically, we estimate that the simulated trend in the aerosol effect would be $-3.5 \mathrm{~W} \mathrm{~m}^{-2}$ decade $^{-1}$ if AM3 was forced with the SYN albedo. This suggests that AM3 overestimates the decrease in the aerosol effect by 1 to $2 \mathrm{~W} \mathrm{~m}^{-2}$ decade $^{-1}$. Many factors could contribute to this bias. Here we focus on the seasonality of the emissions of black carbon and ammonium nitrate precursors. Black carbon is the largest contributor to aerosol absorption over India $\left(+3.2 \mathrm{~W} \mathrm{~m}^{-2}\right.$ on average in winter). Its increase cancels out one-third $\left(0.9 \mathrm{~W} \mathrm{~m}^{-2} \mathrm{decade}^{-1}\right)$ of the decrease in the aerosol effect, much more than in the US and Europe. This is likely to be an underestimate as the prevalent use of biofuel in winter for heating, a large source of black carbon (Yevich and Logan, 2003; Pan et al., 2015), is not represented in the CMIP6 emission inventory. Nitrate dominates changes in the aerosol scattering in winter $\left(-2.4 \mathrm{~W} \mathrm{~m}^{-2}\right.$ decade $\left.^{-1}\right)$. This is consistent with previous multi-model assessments, which have shown that models that do not include nitrate severely underestimate the AOD over India (Pan et al., 2015). Nitrate is formed via the reaction of ammonia (primarily from agriculture) and nitric acid (from the oxidation of NO, whose emissions are dominated by fossil fuel combustion). Nitrate remains challenging to represent in models because of uncertainties in both ammonia emissions and its chemistry and removal (Heald et al., 2012; Paulot et al., 2016). In particu- lar, the seasonality of Indian ammonia emissions in CMIP6 is based on European emissions and peak in spring. In contrast, Warner et al. (2017) recently showed that the ammonia column peaks in summer over India (Fig. S2). Using AM3, we estimate that modulating ammonia emissions with the seasonality derived from satellite information would reduce the simulated trend in the aerosol effect in winter from -2.7 to $-1.9 \mathrm{~W} \mathrm{~m}^{-2}$ decade $^{-1}$. This suggests that uncertainties in the seasonalities of black carbon and ammonia emissions alone could explain most of the discrepancy between observed and simulated changes in the wintertime aerosol effect.

In the pre-monsoon season, the AOD changes much less rapidly than in winter (Fig. 6, Table 1). For instance, MODIS (Terra) AOD increases by 0.04 decade $^{-1}$, less than a third of the rate in winter. This seasonal contrast is not captured by AM3, which simulates a similar change $\left(0.15 \mathrm{decade}^{-1}\right)$ in both seasons (Table 1). This discrepancy can be partly explained by the decrease of the dust optical depth (dashed black line, -0.07 decade $^{-1}$ ) diagnosed from MODIS following Ginoux et al. (2012). This decline, which is not captured by AM3, is supported by the decline of coarsemode aerosols in the Indo-Gangetic Plain (Babu et al., 2013). Using the simulated relationship between the dust optical depth and the dust aerosol effect, we estimate that the reduction in dust optical depth has caused an increase in the aerosol effect of $1.4 \mathrm{~W} \mathrm{~m}^{-2}$ decade $^{-1}$. This suggests that the decline of dust accounts for most of the discrepancy between the model $\left(-3.1 \mathrm{~W} \mathrm{~m}^{-2}\right.$ decade $\left.^{-1}\right)$ and the observational estimates of changes in the aerosol effect $(-0.9$ to $-1.4 \mathrm{~W} \mathrm{~m}^{-2}$ decade $^{-1}$ ). 


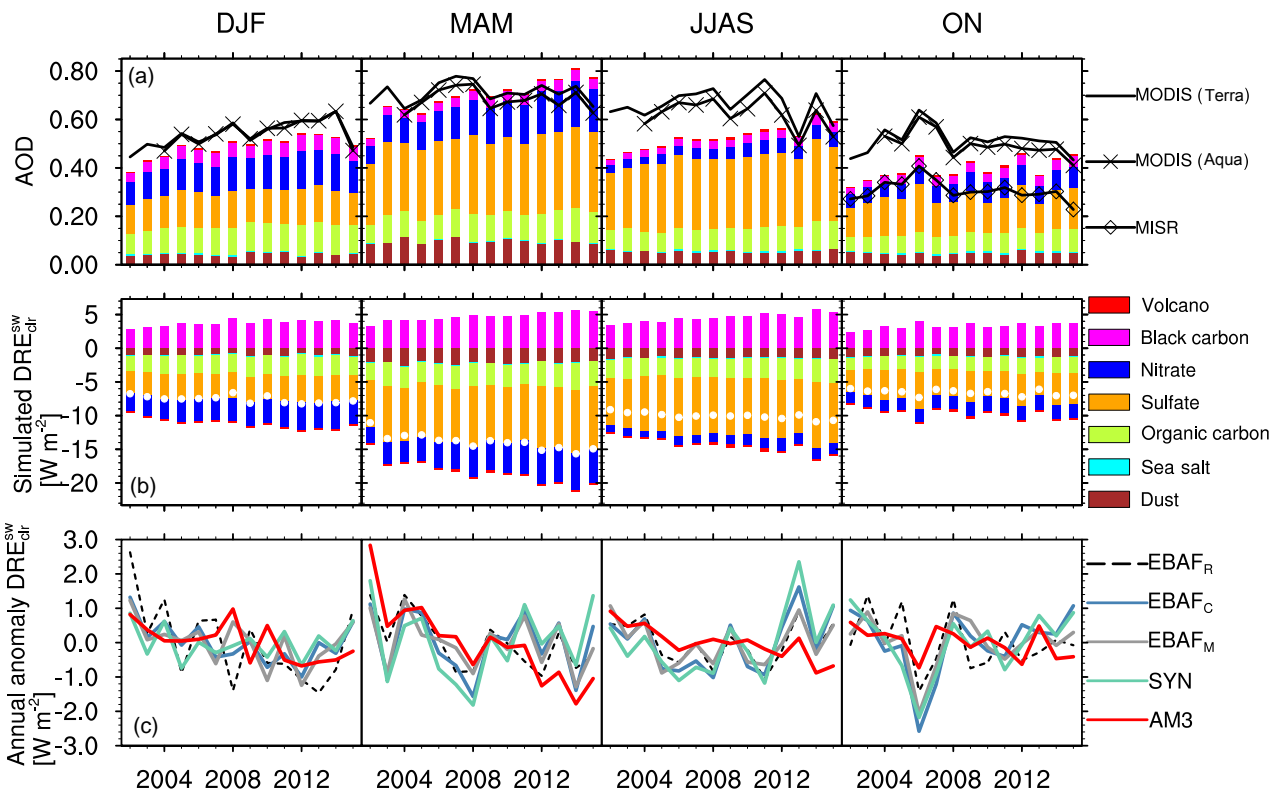

Figure 7. Same as Fig. 4 but for eastern China. MISR is excluded in winter, spring, and monsoon seasons, when its coverage is too sparse.

Jin and Wang (2018) recently suggested that an increase in rainfall in northwestern India has caused a regional greening, which has been accompanied by a reduction of dust emissions. This mechanism may explain why the Goddard Chemistry Aerosol Radiation and Transport (GOCART) model, which includes the modulation of dust emissions by LAI (Kim et al., 2013), captures the decrease of dust in this region (Babu et al., 2013). This suggests that the impact of increasing anthropogenic aerosols on the outgoing radiation may have been masked by regional greening both directly (via the decrease of the surface albedo) and indirectly (via lower dust emissions).

\subsubsection{Eastern China}

Figure 7 shows the change in AOD and aerosol effect over eastern China. AM3 captures the average magnitude of AOD well in winter and spring but underestimates AOD (MODIS) during the monsoon and post-monsoon seasons (Table 1). Although there are significant differences between the different AOD retrievals (Zhao et al., 2017), no significant trend is detected in either the AOD or the aerosol effect over the entire 2001-2015 period in any season.

In contrast to observations, the simulated AOD and aerosol effect exhibit significant changes in both spring ( 0.15 decade $^{-1}$ and $-2.1 \mathrm{~W} \mathrm{~m}^{-2}$ decade $^{-1}$, respectively) and summer $\left(0.11\right.$ decade $^{-1}$ and $-1 \mathrm{~W} \mathrm{~m}^{-2}$ decade $^{-1}$, respectively). In spring, sulfate is the largest contributor to the AOD and aerosol effect but changes are dominated by nitrate aerosols $\left(0.08\right.$ decade $^{-1}$ and $-2.2 \mathrm{~W} \mathrm{~m}^{-2}$ decade $^{-1}$, respectively (Table 1). This large springtime change in nitrate is associated with the May maximum of ammonia emissions in the CMIP6 emission inventory.

Similar to India, the model bias may be associated with uncertainties in anthropogenic emissions. As noted in Sect. 2.1, there are significant differences between the CMIP6 and MEIC emission inventories for $\mathrm{SO}_{2}$ after 2007 and NO after 2013 (Fig. 1). A detailed evaluation of these two emission inventories is beyond the scope of this study. However, observations show significant declines in $\mathrm{SO}_{2}$ columns starting in 2008 ( $\mathrm{Li}$ et al., 2010; Irie et al., 2016; de Foy et al., 2016; Liu et al., 2016; Ding et al., 2017; van der A et al., 2017; Krotkov et al., 2016) and $\mathrm{NO}_{2}$ starting in 2012 (Liu et al., 2016; van der A et al., 2017), consistent with MEIC emissions. We refer the reader to the study from van der A et al. (2017) for a detailed discussion of the technological and regulatory changes that have contributed to the changes in Chinese emissions over the 2001-2015 period.

To quantify the sensitivity of our results to these uncertainties, we perform another simulation replacing the CMIP6 emission with the MEIC emissions for $\mathrm{NO}, \mathrm{BC}, \mathrm{SO}_{2}$, and $\mathrm{NH}_{3}$ over China. We find that the reduction of $\mathrm{SO}_{2}$ emissions after 2007 reduces the simulated trend in springtime AOD by $40 \%$ from 0.15 to 0.09 decade $^{-1}$, which is in better agreement with observations (Fig. S3). In contrast, the simulated trend of the springtime aerosol effect changes by less than $15 \%$ relative to the simulation driven by CMIP6 emissions. This primarily reflects the decrease of both black carbon and $\mathrm{SO}_{2}$ emissions starting in 2007 (Fig. 1), which results in opposite changes in the aerosol effect. Similar to India (in winter), the discrepancy between the model performances for $\mathrm{AOD}$ and $\mathrm{DRE}_{\mathrm{sw}}^{\mathrm{clr}}$ trends points to a bias in aerosol properties. In particular, MEIC suggests that $\mathrm{BC}$ emissions 


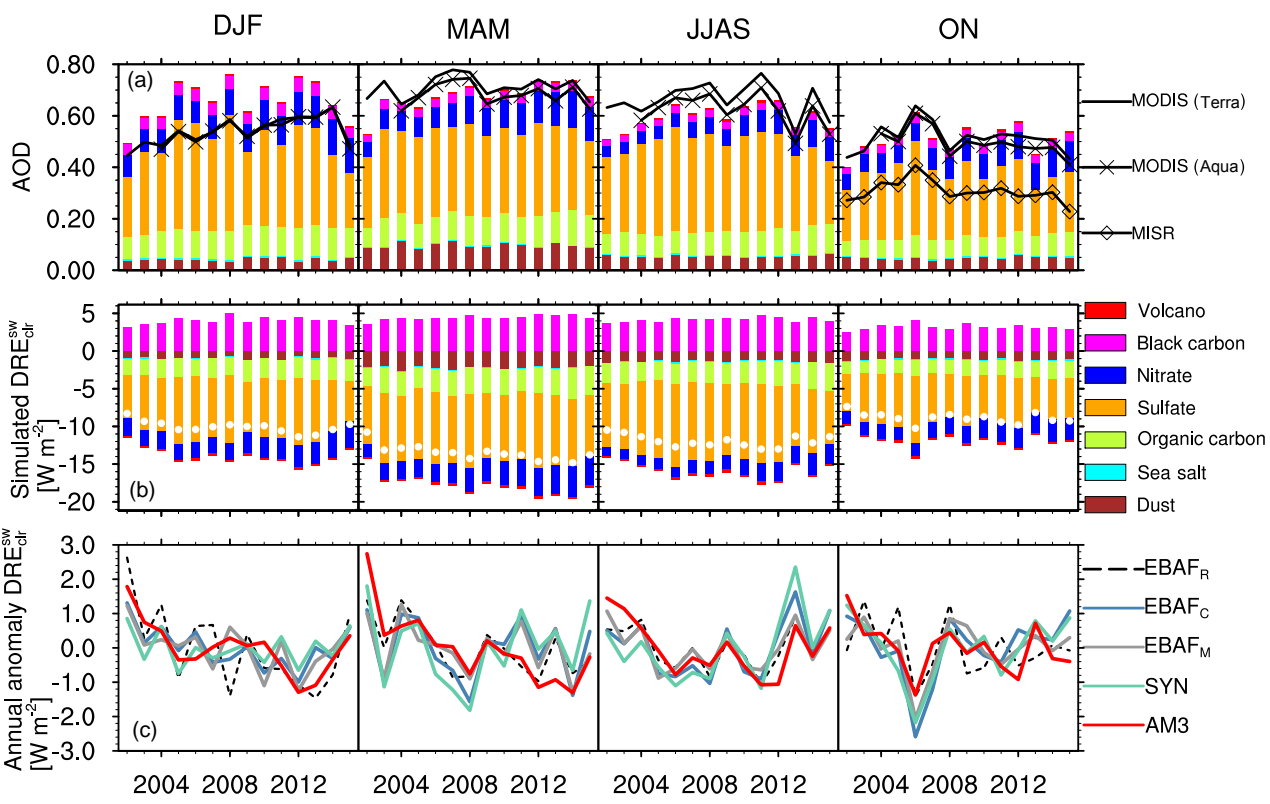

Figure 8. Same as Fig. 7 but including the heterogeneous oxidation of $\mathrm{SO}_{2}$ and MEIC emissions over China (see text).

have remained stable from 2005 until 2013. If BC emissions increased over this time period instead, as in the historical CMIP6 emissions, the change in the simulated DRE $E_{\text {clr }}^{\mathrm{sw}}$ would be reduced without a significant impact on the simulated AOD.

Errors in the representation of the photochemical production of aerosols may also contribute to the model bias. Recent studies have shown that the heterogeneous oxidation of $\mathrm{SO}_{2}$ by $\mathrm{NO}_{2}$ (Cheng et al., 2016) and $\mathrm{O}_{2}$ (Hung and Hoffmann, 2015) at the surface of or in aerosols may be an important source of sulfate in the North China Plains (Y. Wang et al., 2014; Zheng et al., 2015; Guo et al., 2017; He et al., 2018). To examine the sensitivity of our simulation to this chemistry, we perform an additional simulation using MEIC emissions and the parameterization of the heterogeneous production of sulfate on aerosols from Zheng et al. (2015) (Fig. 8). We find that the heterogeneous oxidation of sulfate increases the simulated sulfate optical depth by $100 \%$ in winter and $62 \%$ in fall, relative to the simulation driven by MEIC emissions. In contrast, changes are much smaller $(<25 \%)$ in spring and summer, which reflects the greater availability of oxidants. The increased production of sulfate in winter and fall results in a stronger link between $\mathrm{SO}_{2}$ emissions and the simulated AOD and aerosol effect (Fig. 8). This stronger link allows the model to better capture some prominent features in the observational record, such as the dip in the aerosol effect in fall 2006 (peak in AOD) or the AOD decrease after 2013. This suggests that both changes to the CMIP6 emissions and to the representation of $\mathrm{SO}_{2}$ photochemistry are needed for AM3 to capture observed changes in the aerosol effect over China from 2001 to 2015.

\section{Implication for the aerosol direct forcing}

In Sect. 3.2, we have shown that regional differences in the speciation of anthropogenic emissions (e.g., the ratio of ammonia and $\mathrm{BC}$ to $\mathrm{SO}_{2}$ ) and the oxidative environment are important to understand changes in the direct shortwave aerosol radiative effect under clear-sky over the largest sources of anthropogenic pollution.

Figure 9 shows the changes in the meridional distribution of $\mathrm{BC}, \mathrm{NO}, \mathrm{NH}_{3}$, and $\mathrm{SO}_{2}$ anthropogenic emissions between 1850 and 2001 (panel a) and between 2001 and 2015 (panel b). In particular, the 2001-2015 period is characterized by higher emissions of $\mathrm{BC}(25 \%), \mathrm{NO}(15 \%)$, and $\mathrm{NH}_{3}$ $(19 \%)$ and lower $\mathrm{SO}_{2}$ emissions $(-12.5 \%)$, relative to the 1850-2001 period. While $\mathrm{BC}$ and $\mathrm{NH}_{3}$ emissions have increased in most regions, the change in $\mathrm{SO}_{2}$ and $\mathrm{NO}$ emissions is associated with a decline in the northern midlatitudes and an increase in the tropics. Here, we quantify the associated changes in the meridional distribution of the aerosol direct radiative forcing (DRF), the anthropogenic component of the aerosol direct radiative effect.

The aerosol direct radiative forcing for year $y$ is calculated as follows:

$$
\begin{aligned}
\operatorname{DRF}(y)= & \operatorname{DRE}(\text { anthro }=y, \text { met }=y) \\
& -\operatorname{DRE}(\text { anthro }=1850, \text { met }=y),
\end{aligned}
$$

where anthro and met denote the year used for anthropogenic emissions and to nudge the horizontal wind, respectively. Note that we use the same meteorology for both simulations, in order to minimize differences in natural sources (e.g., dust, sea salt, dimethylsulfide). On the basis of our 

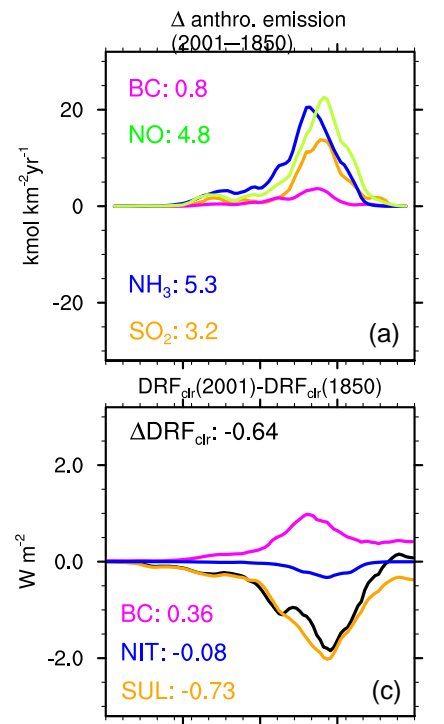

$\operatorname{DRF}(2001)-\operatorname{DRF}(1850)$

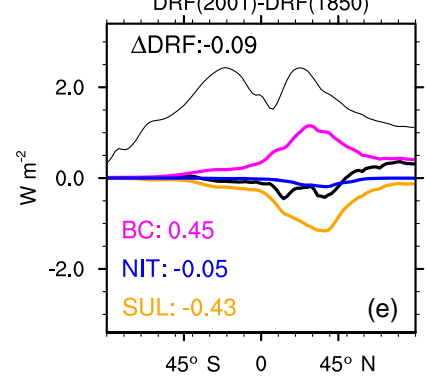

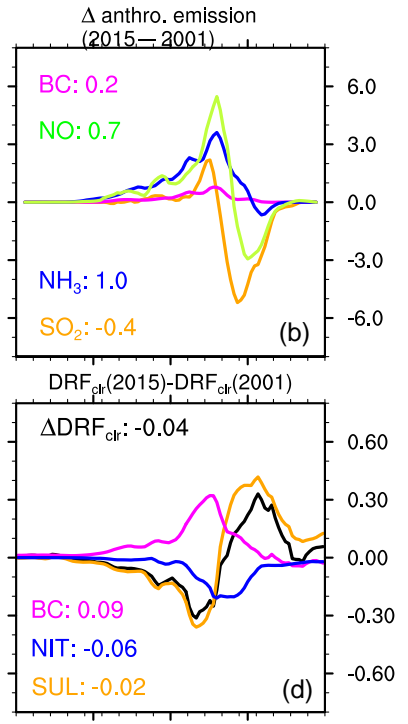

DRF(2015)-DRF(2001)

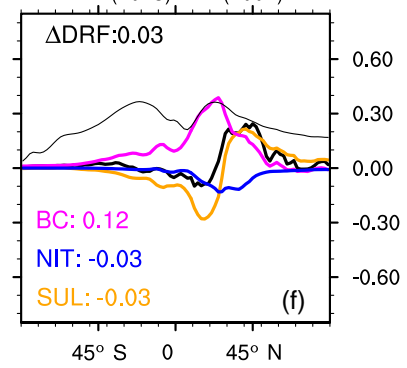

Figure 9. Meridional distribution of changes in anthropogenic emissions (BC, $\mathrm{NO}, \mathrm{NH}_{3}$, and $\left.\mathrm{SO}_{2}\right)$ and in clear-sky $\left(\mathrm{DRF}_{\mathrm{clr}}, \mathbf{c}, \mathbf{d}\right)$ and all-sky radiative aerosol direct radiative forcing (DRF, $\mathbf{e}, \mathbf{f}$ ) from 1850 to 2001 (a, c, e) and from 2001 to 2015 (b, d, f). The thin black line indicates the instantaneous radiative forcing at TOA from wellmixed greenhouse gases. Global anthropogenic emissions and the total and speciated $\mathrm{DRF}_{\mathrm{clr}}$ and DRF are indicated inline. SUL and NIT denote ammonium sulfate and ammonium nitrate, respectively.

evaluation of AM3, we include MEIC emissions for China, the seasonality of $\mathrm{NH}_{3}$ from AIRS in India, and the heterogeneous oxidation of $\mathrm{SO}_{2}$ on aerosol surfaces. We estimate the forcing from biomass burning and non-biomass burning sources separately, as the contribution of anthropogenic activities to changes in biomass burning emissions remains uncertain (Heald et al., 2014). The average 2001-2015 simulated direct radiative forcing from fires is $-0.011 \mathrm{~W} \mathrm{~m}^{-2}$, which falls within the range of previous model assessments $\left(0.0 \pm 0.05 \mathrm{~W} \mathrm{~m}^{-2}\right.$; Myhre et al., 2013). In the following we focus on the radiative forcing from non-biomass burning sources from 1850 to 2001 and from 2001 to 2015.

\subsection{Clear-sky aerosol direct radiative forcing}

The aerosol clear-sky direct radiative forcing in 2001 relative to 1850 is $-0.64 \mathrm{~W} \mathrm{~m}^{-2}$, which agrees well with previous assessments (Table S4). This forcing is dominated by

changes in sulfate $\left(-0.73 \mathrm{~W} \mathrm{~m}^{-2}\right)$, which are partly offset by changes in $\mathrm{BC}\left(+0.36 \mathrm{~W} \mathrm{~m}^{-2}\right)$. Figure $9 \mathrm{c}$ shows that the meridional distribution of the clear-sky radiative forcings of individual aerosols in 2001 relative to 1850 largely mirror that of their precursors' emissions. However, some deviations can be noted. For instance, the forcing from black carbon is enhanced at high latitudes because of the higher surface albedo (Myhre et al., 2013).

We find little change in the aerosol clear-sky direct radiative forcing in 2015 relative to $2001\left(-0.04 \mathrm{~W} \mathrm{~m}^{-2}\right)$, which is consistent with previous studies (Murphy, 2013; Kühn et al., 2014). In AM3, this reflects the cancellation between the positive clear-sky aerosol direct radiative forcing in the northern midlatitudes (associated with the decrease of sulfate and the increase of BC) and the negative clear-sky aerosol direct radiative forcing in the northern tropics (associated with the increase of nitrate and sulfate aerosols).

Next we examine the sensitivity of individual forcings to anthropogenic emissions in both periods. The clear-sky direct radiative forcing of black carbon increases by $25 \%$ from 2001 to 2015, which is in good agreement with the change in $\mathrm{BC}$ emissions. In contrast, the clear-sky direct radiative forcing of sulfate changes little between 2001 and $2015(+3 \%)$, while $\mathrm{SO}_{2}$ emissions decline by $-12.5 \%$ over the same time period. This small change in the sulfate forcing reflects the cancellation between opposite changes in the tropics, where the forcing from sulfate aerosols is negative, and the midlatitudes, where it is positive. AM3 shows a stronger sensitivity of the sulfate forcing to changes in $\mathrm{SO}_{2}$ emissions in the tropics than in the midlatitudes. This difference can be attributed to regional differences in the oxidative environment, as (a) greater actinic flux allows for more efficient oxidation of $\mathrm{SO}_{2}$ in the tropics than in the midlatitudes (Fig. S4), and (b) the efficiency of the oxidation of $\mathrm{SO}_{2}$ to sulfate tends to increase with decreasing $\mathrm{SO}_{2}$ emissions, as oxidant limitations become less important, which diminishes the sensitivity of sulfate to changes in $\mathrm{SO}_{2}$ emissions in the midlatitudes (Fig. S4).

In contrast to sulfate, the change in the clear-sky direct radiative forcing from nitrate from 2001 to $2015(+75 \%)$ is greater than the change in the emissions of its precursors (ammonia and NO emissions increase by less than $20 \%$ ). The higher sensitivity of nitrate to emission changes in the 2001-2015 period is consistent with the decrease of sulfate in the northern midlatitudes, which enables more ammonia to react with nitric acid to produce ammonium nitrate (Ansari and Pandis, 1998). In the tropics, ammonia is less limiting (the ratio of ammonia to $\mathrm{SO}_{2}$ emissions is higher) and the magnitude of both nitrate and sulfate forcings are simulated to increase from 2001 to 2015.

\subsection{All-sky aerosol direct radiative forcing}

Clouds can enhance the reflectivity of the surface beneath aerosols as well as mask the effect of aerosols underneath 
(Heald et al., 2014). Overall, clouds tend to amplify the forcing of absorbing aerosols and diminish that of scattering aerosols. The simulated aerosol forcing in 2001 is $-0.09 \mathrm{~W} \mathrm{~m}^{-2}$, which is at the low end of previous multimodel assessments $\left(-0.27 \pm 0.15 \mathrm{~W} \mathrm{~m}^{-2}\right.$; Myhre et al. 2013; Table S4) and switches sign from negative to positive north of $45^{\circ}$. For comparison, the instantaneous radiative forcing from well-mixed greenhouse gases at TOA, as calculated from the GFDL standalone radiation code (Schwarzkopf and Ramaswamy, 1999; Freidenreich and Ramaswamy, 1999), is $+1.84 \mathrm{~W} \mathrm{~m}^{-2}$ in 2001 .

From 2001 to 2015, the direct aerosol forcing is simulated to be $+0.03 \mathrm{~W} \mathrm{~m}^{-2}$, including $+0.12,-0.03$, and $-0.03 \mathrm{~W} \mathrm{~m}^{-2}$ from black carbon, sulfate, and nitrate, respectively. Myhre et al. (2017) recently reported a similar change in the overall direct radiative forcing $\left(+0.01 \mathrm{~W} \mathrm{~m}^{-2}\right)$ but different contributions from sulfate $\left(+0.03 \mathrm{~W} \mathrm{~m}^{-2}\right)$ and black carbon $\left(+0.03 \mathrm{~W} \mathrm{~m}^{-2}\right)$. Many factors could contribute to these differences including the radiative properties of aerosols (e.g., the mixing of sulfate with black carbon; Bond et al., 2013) and the emission inventories. Further studies are needed to examine whether changes in the sensitivity of radiative forcing to anthropogenic emissions are robust across models. Such assessment would be especially important in the northern midlatitudes, where the direct radiative forcing from aerosols and greenhouse gases from 2001 to 2015 are simulated to be of similar magnitude $\left(+0.25 \mathrm{~W} \mathrm{~m}^{-2}\right)$.

\section{Conclusions}

We have derived estimates of the changes in the aerosol direct clear-sky shortwave radiative effect from 2001 to 2015 using variations in the outgoing shortwave clear-sky radiation from CERES EBAF. Even over polluted regions, such changes can not be solely ascribed to aerosols and the impact of changes in surface albedo, water vapor, and ozone on outgoing radiation need to be accounted for. In particular, we have shown that the effect of increasing anthropogenic aerosols on the outgoing radiation has been largely masked by a decrease in surface albedo over India.

We have used observed seasonal changes in AOD and the aerosol effect over large source regions of anthropogenic emissions to assess the representation of anthropogenic emissions and their impact on atmospheric chemistry and the aerosol direct radiative effect in the GFDL AM3 global chemistry-climate model. Such observational constraints may be especially valuable for future multi-model assessments.

Our work suggests a mature understanding of changes in the aerosol effect over the US and Europe, where the decrease of sulfate aerosols accounts for most of the increase (i.e., the weakening) in the aerosol direct clear-sky shortwave radiative effect. In contrast, the different mix of anthropogenic emissions in India and China results in a more complex speciation of aerosols responsible for changes in the aerosol direct effect, with large contributions from sulfate, nitrate, and black carbon. Trends in these regions remain challenging to capture in the GFDL AM3 model. Some of these biases may be model-specific, including the treatment of the mixing between sulfate and black carbon, the representation of the photochemistry of sulfate and nitrate, or the representation of dust emissions. Others are attributed to the CMIP6 emissions and will likely affect other models. In particular, we find that the model bias in winter over India can be largely accounted for by uncertainties in the seasonality of ammonia and black carbon emissions. Similarly, comparisons between the CMIP6 and MEIC emission inventories over China suggest that the model bias in this region can be largely attributed to an underestimate of the reduction of $\mathrm{SO}_{2}$ emissions after 2007 in CMIP6.

Our study shows that regional differences in the emission mix and oxidative conditions have a large impact on the relationship between anthropogenic emissions and direct aerosol forcing. Specifically, we have shown that changes in the magnitude, speciation, and spatial distribution of anthropogenic emissions have dampened the sensitivity of the aerosol forcing to $\mathrm{SO}_{2}$ emissions, but amplified them to emissions of $\mathrm{NO}$ and ammonia, the precursors of nitrate aerosols. This suggests that relationships between anthropogenic emissions and aerosol forcing derived over the 1850-2001 period and, thus, largely controlled by changes of $\mathrm{SO}_{2}$ in Europe and North America (Stevens and Schwartz, 2012) need to be revisited with an emphasis on black carbon and ammonia in Asia.

Data availability. CERES data were obtained from the NASA Langley Research Center CERES ordering tool at http://ceres.larc.nasa. gov/ (NASA's Langley Research Center, last accessed 29 October 2017). The MODIS albedo product (MD43C3 MODIS/Terra+Aqua BRDF/Albedo Albedo Daily L3 Global 0.05 Deg CMG V006) was obtained in netCDF file format from Stefan Kern at the Integrated Climate Data Center (ICDC, http://icdc.cen.uni-hamburg.de, last access: 18 September 2017, University of Hamburg, Hamburg, Germany). MISR and MODIS AOD products can be obtained from the NASA Earthdata portal. Model outputs are available upon request from fabien.paulot@noaa.gov. Instructions to run the AM3 model are available at https://www.gfdl.noaa.gov/am3/ (last access: 10 September 2018).

Supplement. The supplement related to this article is available online at: https://doi.org/10.5194/acp-18-13265-2018-supplement.

Author contributions. FP, DP, and LWH designed the research. FP implemented the calculation of the individual aerosol components of the DRE in AM3, performed the simulations, and processed CERES and MODIS data. VN provided AM3-ready CMIP6 emis- 
sions. PG provided MODIS dust optical depth. FP and DP analyzed the results and wrote the paper with inputs from all authors.

Competing interests. The authors declare that they have no conflict of interest.

Acknowledgements. We thank the many researchers, who have contributed to the CERES, MODIS, and MISR products used in this study. We thank Bo Zheng and Qiang Zhang for providing MEIC gridded emissions. This work was supported by the NOAA Climate Program Office. Paul Ginoux acknowledges partial funding by NASA through a NNH14ZDA001N-ACMAP grant. We thank Alexandra Jones, Leo J. Donner, and two anonymous reviewers for helpful comments. All figures were generated using the NCAR Command Language (Version 6.4.0, https://doi.org/10.5065/D6WD3XH5).

Edited by: Anne Perring

Reviewed by: two anonymous referees

\section{References}

Alfaro-Contreras, R., Zhang, J., Reid, J. S., and Christopher, S.: A study of 15-year aerosol optical thickness and direct shortwave aerosol radiative effect trends using MODIS, MISR, CALIOP and CERES, Atmos. Chem. Phys., 17, 13849-13868, https://doi.org/10.5194/acp-17-13849-2017, 2017.

Ansari, A. S. and Pandis, S. N.: Response of Inorganic PM to Precursor Concentrations, Environ. Sci. Technol., 32, 2706-2714, 1998.

Babu, S. S., Manoj, M. R., Moorthy, K. K., Gogoi, M. M., Nair, V. S., Kompalli, S. K., Satheesh, S. K., Niranjan, K., Ramagopal, K., Bhuyan, P. K., and Singh, D.: Trends in aerosol optical depth over Indian region: Potential causes and impact indicators, J. Geophys. Res.-Atmos., 118, 11794-11806, https://doi.org/10.1002/2013JD020507, 2013.

Bellouin, N., Boucher, O., Haywood, J., and Reddy, M. S.: Global estimate of aerosol direct radiative forcing from satellite measurements, Nature, 438, 1138-1141, https://doi.org/10.1038/nature04348, 2005.

Bellouin, N., Jones, A., Haywood, J., and Christopher, S. A.: Updated estimate of aerosol direct radiative forcing from satellite observations and comparison against the Hadley Centre climate model, J. Geophys. Res.-Atmos., 113, D10205, https://doi.org/10.1029/2007JD009385, 2008.

Bollasina, M. A., Ming, Y., and Ramaswamy, V.: Anthropogenic Aerosols and the Weakening of the South Asian Summer Monsoon, Science, 334, 502-505, https://doi.org/10.1126/science.1204994, 2011.

Bond, T. C., Doherty, S. J., Fahey, D. W., Forster, P. M., Berntsen, T., DeAngelo, B. J., Flanner, M. G., Ghan, S., Kärcher, B., Koch, D., Kinne, S., Kondo, Y., Quinn, P. K., Sarofim, M. C., Schultz, M. G., Schulz, M., Venkataraman, C., Zhang, H., Zhang, S., Bellouin, N., Guttikunda, S. K., Hopke, P. K., Jacobson, M. Z., Kaiser, J. W., Klimont, Z., Lohmann, U., Schwarz, J. P., Shindell, D., Storelvmo, T., Warren, S. G., and Zender, C. S.:
Bounding the role of black carbon in the climate system: A scientific assessment, J. Geophys. Res.-Atmos., 118, 5380-5552, https://doi.org/10.1002/jgrd.50171, 2013.

Boucher, O., Randall, D., Artaxo, P., Bretherton, C., Feingold, G., Forster, P., Kerminen, V.-M., Kondo, Y., Liao, H., Lohmann, U., Rasch, P., Satheesh, S., Sherwood, S., Stevens, B., and Zhang, X.: Clouds and Aerosols, book section 7, 571-658, Cambridge University Press, Cambridge, UK and New York, NY, USA, https://doi.org/10.1017/CBO9781107415324.016, 2013.

Cescatti, A., Marcolla, B., Santhana Vannan, S. K., Pan, J. Y., Román, M. O., Yang, X., Ciais, P., Cook, R. B., Law, B. E., Matteucci, G., Migliavacca, M., Moors, E., Richardson, A. D., Seufert, G., and Schaaf, C. B.: Intercomparison of MODIS albedo retrievals and in situ measurements across the global FLUXNET network, Remote Sens. Environ., 121, 323-334, https://doi.org/10.1016/j.rse.2012.02.019, 2012.

Charlson, R. J., Schwartz, S. E., Hales, J. M., Cess, R. D., Coakley, J. A., Hansen, J. E., and Hofmann, D. J.: Climate Forcing by Anthropogenic Aerosols, Science, 255, 423-430, https://doi.org/10.1126/science.255.5043.423, 1992.

Cheng, Y., Zheng, G., Wei, C., Mu, Q., Zheng, B., Wang, Z., Gao, M., Zhang, Q., He, K., Carmichael, G., Pöschl, U., and Su, H.: Reactive nitrogen chemistry in aerosol water as a source of sulfate during haze events in China, Sci. Adv., 2, e1601530, https://doi.org/10.1126/sciadv.1601530, 2016.

Christopher, S. A. and Zhang, J.: Cloud-free shortwave aerosol radiative effect over oceans: Strategies for identifying anthropogenic forcing from Terra satellite measurements, Geophys. Res. Lett., 31, L18101, https://doi.org/10.1029/2004GL020510, 2004.

CMIP6 Data Request: Data Request Section: CMORvar, available at: http://clipc-services.ceda.ac.uk/dreq/index/CMORvar. html, last access: 2 June 2017.

Collins, W. D., Rasch, P. J., Eaton, B. E., Khattatov, B. V., Lamarque, J.-F., and Zender, C. S.: Simulating aerosols using a chemical transport model with assimilation of satellite aerosol retrievals: Methodology for INDOEX, J. Geophys. Res.-Atmos., 106, 7313-7336, https://doi.org/10.1029/2000JD900507, 2001.

de Foy, B., Lu, Z., and Streets, D. G.: Satellite $\mathrm{NO}_{2}$ retrievals suggest China has exceeded its $\mathrm{NO}_{x}$ reduction goals from the twelfth Five-Year Plan, Sci. Rep., 6, 35912, https://doi.org/10.1038/srep35912, 2016.

Dentener, F., Kinne, S., Bond, T., Boucher, O., Cofala, J., Generoso, S., Ginoux, P., Gong, S., Hoelzemann, J. J., Ito, A., Marelli, L., Penner, J. E., Putaud, J.-P., Textor, C., Schulz, M., van der Werf, G. R., and Wilson, J.: Emissions of primary aerosol and precursor gases in the years 2000 and 1750 prescribed data-sets for AeroCom, Atmos. Chem. Phys., 6, 43214344, https://doi.org/10.5194/acp-6-4321-2006, 2006.

Ding, J., Miyazaki, K., van der A, R. J., Mijling, B., Kurokawa, J.-I., Cho, S., Janssens-Maenhout, G., Zhang, Q., Liu, F., and Levelt, P. F.: Intercomparison of $\mathrm{NO}_{x}$ emission inventories over East Asia, Atmos. Chem. Phys., 17, 10125-10141, https://doi.org/10.5194/acp-17-10125-2017, 2017.

Donner, L. J., Wyman, B. L., Hemler, R. S., Horowitz, L. W., Ming, Y., Zhao, M., Golaz, J.-C., Ginoux, P., Lin, S.-J., Schwarzkopf, M. D., Austin, J., Alaka, G., Cooke, W. F., Delworth, T. L., Freidenreich, S. M., Gordon, C. T., Griffies, S. M., Held, I. M., Hurlin, W. J., Klein, S. A., Knutson, T. R., Langenhorst, A. R., 
Lee, H.-C., Lin, Y., Magi, B. I., Malyshev, S. L., Milly, P. C. D., Naik, V., Nath, M. J., Pincus, R., Ploshay, J. J., Ramaswamy, V., Seman, C. J., Shevliakova, E., Sirutis, J. J., Stern, W. F., Stouffer, R. J., Wilson, R. J., Winton, M., Wittenberg, A. T., and Zeng, F.: The Dynamical Core, Physical Parameterizations, and Basic Simulation Characteristics of the Atmospheric Component AM3 of the GFDL Global Coupled Model CM3, J. Climate, 24, 34843519, 2011.

Freidenreich, S. M. and Ramaswamy, V.: A new multipleband solar radiative parameterization for general circulation models, J. Geophys. Res.-Atmos., 104, 31389-31409, https://doi.org/10.1029/1999jd900456, 1999.

Ginoux, P., Prospero, J. M., Gill, T. E., Hsu, N. C., and Zhao, M.: Global-scale attribution of anthropogenic and natural dust sources and their emission rates based on MODIS Deep Blue aerosol products, Rev. Geophys., 50, RG3005, https://doi.org/10.1029/2012RG000388, 2012.

Griffies, S. M., Winton, M., Donner, L. J., Horowitz, L. W., Downes, S. M., Farneti, R., Gnanadesikan, A., Hurlin, W. J., Lee, H.-C., Liang, Z., Palter, J. B., Samuels, B. L., Wittenberg, A. T., Wyman, B. L., Yin, J., and Zadeh, N.: The GFDL CM3 Coupled Climate Model: Characteristics of the Ocean and Sea Ice Simulations, J. Climate, 24, 3520-3544, https://doi.org/10.1175/2011JCLI3964.1, 2011.

Guenther, A., Karl, T., Harley, P., Wiedinmyer, C., Palmer, P. I., and Geron, C.: Estimates of global terrestrial isoprene emissions using MEGAN (Model of Emissions of Gases and Aerosols from Nature), Atmos. Chem. Phys., 6, 3181-3210, https://doi.org/10.5194/acp-6-3181-2006, 2006.

Guo, H., Weber, R. J., and Nenes, A.: High levels of ammonia do not raise fine particle $\mathrm{pH}$ sufficiently to yield nitrogen oxide-dominated sulfate production, Sci. Rep., 7, 12109, https://doi.org/10.1038/s41598-017-11704-0, 2017.

He, P., Alexander, B., Geng, L., Chi, X., Fan, S., Zhan, H., Kang, H., Zheng, G., Cheng, Y., Su, H., Liu, C., and Xie, Z.: Isotopic constraints on heterogeneous sulfate production in Beijing haze, Atmos. Chem. Phys., 18, 5515-5528, https://doi.org/10.5194/acp18-5515-2018, 2018.

Heald, C. L., Collett Jr., J. L., Lee, T., Benedict, K. B., Schwandner, F. M., Li, Y., Clarisse, L., Hurtmans, D. R., Van Damme, M., Clerbaux, C., Coheur, P.-F., Philip, S., Martin, R. V., and Pye, H. O. T.: Atmospheric ammonia and particulate inorganic nitrogen over the United States, Atmos. Chem. Phys., 12, 10295-10312, https://doi.org/10.5194/acp-12-10295-2012, 2012.

Heald, C. L., Ridley, D. A., Kroll, J. H., Barrett, S. R. H., Cady-Pereira, K. E., Alvarado, M. J., and Holmes, C. D.: Contrasting the direct radiative effect and direct radiative forcing of aerosols, Atmos. Chem. Phys., 14, 5513-5527, https://doi.org/10.5194/acp-14-5513-2014, 2014.

Hoesly, R. M., Smith, S. J., Feng, L., Klimont, Z., JanssensMaenhout, G., Pitkanen, T., Seibert, J. J., Vu, L., Andres, R. J., Bolt, R. M., Bond, T. C., Dawidowski, L., Kholod, N., Kurokawa, J.-I., Li, M., Liu, L., Lu, Z., Moura, M. C. P., O'Rourke, P. R., and Zhang, Q.: Historical (1750-2014) anthropogenic emissions of reactive gases and aerosols from the Community Emissions Data System (CEDS), Geosci. Model Dev., 11, 369-408, https://doi.org/10.5194/gmd-11-369-2018, 2018.

Hung, H.-M. and Hoffmann, M. R.: Oxidation of gas-phase $\mathrm{SO}_{2}$ on the surfaces of acidic microdroplets: implications for sulfate and sulfate radical anion formation in the atmospheric liquid phase, Environ. Sci. Technol., 49, 13768-13776, https://doi.org/10.1021/acs.est.5b01658, 2015.

Irie, H., Muto, T., Itahashi, S., Kurokawa, J.-I., and Uno, I.: Turnaround of Tropospheric Nitrogen Dioxide Pollution Trends in China, Japan, and South Korea, Sola, 12, 170-174, https://doi.org/10.2151/sola.2016-035, 2016.

Jin, Q. and Wang, C.: The greening of Northwest Indian subcontinent and reduction of dust abundance resulting from Indian summer monsoon revival, Sci. Rep., 8, 4573, https://doi.org/10.1038/s41598-018-23055-5, 2018.

John, J. G., Fiore, A. M., Naik, V., Horowitz, L. W., and Dunne, J. P.: Climate versus emission drivers of methane lifetime against loss by tropospheric OH from 1860-2100, Atmos. Chem. Phys., 12, 12021-12036, https://doi.org/10.5194/acp-12-12021-2012, 2012.

Kahn, R. A.: Reducing the Uncertainties in Direct Aerosol Radiative Forcing, Surv. Geophys., 33, 701-721, https://doi.org/10.1007/s10712-011-9153-z, 2012.

Kahn, R. A., Gaitley, B. J., Martonchik, J. V., Diner, D. J., Crean, K. A., and Holben, B.: Multiangle Imaging Spectroradiometer (MISR) global aerosol optical depth validation based on 2 years of coincident Aerosol Robotic Network (AERONET) observations, J. Geophys. Res.-Atmos., 110, D10S04, https://doi.org/10.1029/2004JD004706, 2005.

Kahn, R. A., Gaitley, B. J., Garay, M. J., Diner, D. J., Eck, T. F., Smirnov, A., and Holben, B. N.: Multiangle Imaging SpectroRadiometer global aerosol product assessment by comparison with the Aerosol Robotic Network, J. Geophys. Res.-Atmos., 115, D23209, https://doi.org/10.1029/2010JD014601, 2010.

Kalnay, E., Kanamitsu, M., Kistler, R., Collins, W., Deaven, D., Gandin, L., Iredell, M., Saha, S., White, G., Woollen, J., Zhu, Y., Leetmaa, A., Reynolds, R., Chelliah, M., Ebisuzaki, W., Higgins, W., Janowiak, J., Mo, K. C., Ropelewski, C., Wang, J., Jenne, R., and Joseph, D.: The NCEP/NCAR 40-Year Reanalysis Project, B. Am. Meteorol. Soc., 77, 437-471, 1996.

Kendall, M. G.: A new measure of rank correlation, Biometrika, 30, 81-93, https://doi.org/10.1093/biomet/30.1-2.81, 1938.

Kim, D., Chin, M., Bian, H., Tan, Q., Brown, M. E., Zheng, T., You, R., Diehl, T., Ginoux, P., and Kucsera, T.: The effect of the dynamic surface bareness on dust source function, emission, and distribution, J. Geophys. Res.-Atmos., 118, 871-886, https://doi.org/10.1029/2012JD017907, 2013.

Krotkov, N. A., McLinden, C. A., Li, C., Lamsal, L. N., Celarier, E. A., Marchenko, S. V., Swartz, W. H., Bucsela, E. J., Joiner, J., Duncan, B. N., Boersma, K. F., Veefkind, J. P., Levelt, P. F., Fioletov, V. E., Dickerson, R. R., He, H., Lu, Z., and Streets, D. G.: Aura OMI observations of regional $\mathrm{SO}_{2}$ and $\mathrm{NO}_{2}$ pollution changes from 2005 to 2015, Atmos. Chem. Phys., 16, 46054629, https://doi.org/10.5194/acp-16-4605-2016, 2016.

Kühn, T., Partanen, A.-I., Laakso, A., Lu, Z., Bergman, T., Mikkonen, S., Kokkola, H., Korhonen, H., Räisänen, P., Streets, D. G., Romakkaniemi, S., and Laaksonen, A.: Climate impacts of changing aerosol emissions since 1996, Geophys. Res. Lett., 41, 4711-4718, https://doi.org/10.1002/2014gl060349, 2014.

Levy, H., Horowitz, L. W., Schwarzkopf, M. D., Ming, Y., Golaz, J.-C., Naik, V., and Ramaswamy, V.: The roles of aerosol direct and indirect effects in past and future climate change, J. Geophys. Res.-Atmos., 118, 4521-4532, 2013. 
Levy, R. C., Remer, L. A., Kleidman, R. G., Mattoo, S., Ichoku, C., Kahn, R., and Eck, T. F.: Global evaluation of the Collection 5 MODIS dark-target aerosol products over land, Atmos. Chem. Phys., 10, 10399-10420, https://doi.org/10.5194/acp-10-103992010, 2010.

Levy, R. C., Mattoo, S., Munchak, L. A., Remer, L. A., Sayer, A. M., Patadia, F., and Hsu, N. C.: The Collection 6 MODIS aerosol products over land and ocean, Atmos. Meas. Tech., 6, 29893034, https://doi.org/10.5194/amt-6-2989-2013, 2013.

Li, C., Zhang, Q., Krotkov, N. A., Streets, D. G., He, K., Tsay, S.-C., and Gleason, J. F.: Recent large reduction in sulfur dioxide emissions from Chinese power plants observed by the Ozone Monitoring Instrument, Geophys. Res. Lett., 37, L08807, https://doi.org/10.1029/2010GL042594, 2010.

Liu, F., Zhang, Q., A, R. J. v. d., Zheng, B., Tong, D., Yan, L., Zheng, Y., and He, K.: Recent reduction in $\mathrm{NO}_{x}$ emissions over China: synthesis of satellite observations and emission inventories, Environ. Res. Lett., 11, 114002, https://doi.org/10.1088/1748-9326/11/11/114002, 2016.

Loeb, N. G. and Manalo-Smith, N.: Top-of-Atmosphere Direct Radiative Effect of Aerosols over Global Oceans from Merged CERES and MODIS Observations, J. Climate, 18, 3506-3526, https://doi.org/10.1175/JCLI3504.1, 2005.

Loeb, N. G., Doelling, D. R., Wang, H., Su, W., Nguyen, C., Corbett, J. G., Liang, L., Mitrescu, C., Rose, F. G., and Kato, S.: Clouds and the Earth's Radiant Energy System (CERES) Energy Balanced and Filled (EBAF) Top-ofAtmosphere (TOA) Edition-4.0 Data Product, J. Climate, 31, 895-918, https://doi.org/10.1175/jcli-d-17-0208.1, 2018.

Murphy, D. M.: Little net clear-sky radiative forcing from recent regional redistribution of aerosols, Nat. Geosci., 6, 258-262, https://doi.org/10.1038/ngeo1740, 2013.

Myhre, G., Samset, B. H., Schulz, M., Balkanski, Y., Bauer, S., Berntsen, T. K., Bian, H., Bellouin, N., Chin, M., Diehl, T., Easter, R. C., Feichter, J., Ghan, S. J., Hauglustaine, D., Iversen, T., Kinne, S., Kirkevåg, A., Lamarque, J.-F., Lin, G., Liu, X., Lund, M. T., Luo, G., Ma, X., van Noije, T., Penner, J. E., Rasch, P. J., Ruiz, A., Seland, Ø., Skeie, R. B., Stier, P., Takemura, T., Tsigaridis, K., Wang, P., Wang, Z., Xu, L., Yu, H., Yu, F., Yoon, J.-H., Zhang, K., Zhang, H., and Zhou, C.: Radiative forcing of the direct aerosol effect from AeroCom Phase II simulations, Atmos. Chem. Phys., 13, 1853-1877, https://doi.org/10.5194/acp13-1853-2013, 2013.

Myhre, G., Aas, W., Cherian, R., Collins, W., Faluvegi, G., Flanner, M., Forster, P., Hodnebrog, Ø., Klimont, Z., Lund, M. T., Mülmenstädt, J., Lund Myhre, C., Olivié, D., Prather, M., Quaas, J., Samset, B. H., Schnell, J. L., Schulz, M., Shindell, D., Skeie, R. B., Takemura, T., and Tsyro, S.: Multi-model simulations of aerosol and ozone radiative forcing due to anthropogenic emission changes during the period 1990-2015, Atmos. Chem. Phys., 17, 2709-2720, https://doi.org/10.5194/acp17-2709-2017, 2017.

Naik, V., Horowitz, L. W., Fiore, A. M., Ginoux, P., Mao, J., Aghedo, A. M., and Levy, H.: Impact of preindustrial to presentday changes in short-lived pollutant emissions on atmospheric composition and climate forcing, J. Geophys. Res.-Atmos., 118, 8086-8110, 2013.

Pan, X., Chin, M., Gautam, R., Bian, H., Kim, D., Colarco, P. R., Diehl, T. L., Takemura, T., Pozzoli, L., Tsigaridis, K., Bauer,
S., and Bellouin, N.: A multi-model evaluation of aerosols over South Asia: common problems and possible causes, Atmos. Chem. Phys., 15, 5903-5928, https://doi.org/10.5194/acp15-5903-2015, 2015.

Patadia, F., Gupta, P., and Christopher, S. A.: First observational estimates of global clear sky shortwave aerosol direct radiative effect over land, Geophys. Res. Lett., 35, L04810, https://doi.org/10.1029/2007GL032314, 2008.

Paulot, F., Jacob, D. J., Pinder, R. W., Bash, J. O., Travis, K., and Henze, D. K.: Ammonia emissions in the United States, European Union, and China derived by high-resolution inversion of ammonium wet deposition data: Interpretation with a new agricultural emissions inventory (MASAGE_NH3), J. Geophys. Res.-Atmos., 119, 4343-4364, 2014.

Paulot, F., Ginoux, P., Cooke, W. F., Donner, L. J., Fan, S., Lin, M.-Y., Mao, J., Naik, V., and Horowitz, L. W.: Sensitivity of nitrate aerosols to ammonia emissions and to nitrate chemistry: implications for present and future nitrate optical depth, Atmos. Chem. Phys., 16, 1459-1477, https://doi.org/10.5194/acp16-1459-2016, 2016.

Paulot, F., Fan, S., and Horowitz, L. W.: Contrasting seasonal responses of sulfate aerosols to declining $\mathrm{SO}_{2}$ emissions in the Eastern U.S.: Implications for the efficacy of $\mathrm{SO}_{2}$ emission controls, Geophys. Res. Lett., 44, 455-464, https://doi.org/10.1002/2016GL070695, 2017a.

Paulot, F., Paynter, D., Ginoux, P., Naik, V., Whitburn, S., Van Damme, M., Clarisse, L., Coheur, P.-F., and Horowitz, L. W.: Gas-aerosol partitioning of ammonia in biomass burning plumes: Implications for the interpretation of spaceborne observations of ammonia and the radiative forcing of ammonium nitrate, Geophys. Res. Lett., 44, 8084-8093, https://doi.org/10.1002/2017GL074215, 2017b.

Rayner, N. A., Parker, D. E., Horton, E. B., Folland, C. K., Alexander, L. V., Rowell, D. P., Kent, E. C., and Kaplan, A.: Global analyses of sea surface temperature, sea ice, and night marine air temperature since the late nineteenth century, J. Geophys. Res.-Atmos., 108, 4407, https://doi.org/10.1029/2002JD002670, 2003.

Rosenfeld, D., Andreae, M. O., Asmi, A., Chin, M., de Leeuw, G., Donovan, D. P., Kahn, R., Kinne, S., Kivekäs, N., Kulmala, M., Lau, W., Schmidt, K. S., Suni, T., Wagner, T., Wild, M., and Quaas, J.: Global observations of aerosol-cloudprecipitation-climate interactions, Rev. Geophys., 52, 750-808, https://doi.org/10.1002/2013RG000441, 2014.

Rutan, D., Rose, F., Roman, M., Manalo-Smith, N., Schaaf, C., and Charlock, T.: Development and assessment of broadband surface albedo from Clouds and the Earth's Radiant Energy System Clouds and Radiation Swath data product, J. Geophys. Res.Atmos., 114, D08125, https://doi.org/10.1029/2008JD010669, 2009.

Rutan, D. A., Kato, S., Doelling, D. R., Rose, F. G., Nguyen, L. T., Caldwell, T. E., and Loeb, N. G.: CERES Synoptic Product: Methodology and Validation of Surface Radiant Flux, J. Atmos. Ocean. Tech., 32, 1121-1143, https://doi.org/10.1175/JTECHD-14-00165.1, 2015.

Saikawa, E., Kim, H., Zhong, M., Avramov, A., Zhao, Y., JanssensMaenhout, G., Kurokawa, J.-I., Klimont, Z., Wagner, F., Naik, V., Horowitz, L. W., and Zhang, Q.: Comparison of emissions inventories of anthropogenic air pollutants and green- 
house gases in China, Atmos. Chem. Phys., 17, 6393-6421, https://doi.org/10.5194/acp-17-6393-2017, 2017a.

Saikawa, E., Trail, M., Zhong, M., Wu, Q., Young, C. L., JanssensMaenhout, G., Klimont, Z., Wagner, F., ichi Kurokawa, J., Nagpure, A. S., and Gurjar, B. R.: Uncertainties in emissions estimates of greenhouse gases and air pollutants in India and their impacts on regional air quality, Environ. Res. Lett., 12, 065002, https://doi.org/10.1088/1748-9326/aa6cb4, 2017b.

Sayer, A. M., Munchak, L. A., Hsu, N. C., Levy, R. C., Bettenhausen, C., and Jeong, M.-J.: MODIS Collection 6 aerosol products: Comparison between Aqua's e-Deep Blue, Dark Target, and "merged" data sets, and usage recommendations, J. Geophys. Res.-Atmos., 119, 13965-13989, https://doi.org/10.1002/2014JD022453, 2014.

Schaaf, C. B., Gao, F., Strahler, A. H., Lucht, W., Li, X., Tsang, T., Strugnell, N. C., Zhang, X., Jin, Y., Muller, J.-P., Lewis, P., Barnsley, M., Hobson, P., Disney, M., Roberts, G., Dunderdale, M., Doll, C., d'Entremont, R. P., Hu, B., Liang, S., Privette, J. L., and Roy, D.: First operational BRDF, albedo nadir reflectance products from MODIS, Remote Sens. Environ., 83, 135-148, https://doi.org/10.1016/S0034-4257(02)00091-3, 2002.

Schwarzkopf, M. D. and Ramaswamy, V.: Radiative effects of $\mathrm{CH}_{4}$, $\mathrm{N}_{2} \mathrm{O}$, halocarbons and the foreign-broadened $\mathrm{H}_{2} \mathrm{O}$ continuum: A GCM experiment, J. Geophys. Res.-Atmos., 104, 9467-9488, https://doi.org/10.1029/1999jd900003, 1999.

Sen, P. K.: Estimates of the Regression Coefficient Based on Kendall's Tau, J. Am. Stat. Assoc., 63, 1379-1389, https://doi.org/10.1080/01621459.1968.10480934, 1968.

Shell, K. M., Kiehl, J. T., and Shields, C. A.: Using the Radiative Kernel Technique to Calculate Climate Feedbacks in NCAR's Community Atmospheric Model, J. Climate, 21, 2269-2282, https://doi.org/10.1175/2007jcli2044.1, 2008.

Soden, B. J., Held, I. M., Colman, R., Shell, K. M., Kiehl, J. T., and Shields, C. A.: Quantifying Climate Feedbacks Using Radiative Kernels, J. Climate, 21, 3504-3520, https://doi.org/10.1175/2007jcli2110.1, 2008.

Stevens, B.: Rethinking the Lower Bound on Aerosol Radiative Forcing, J. Climate, 28, 4794-4819, https://doi.org/10.1175/JCLI-D-14-00656.1, 2015.

Stevens, B. and Schwartz, S. E.: Observing and Modeling Earth's Energy Flows, Surv. Geophys., 33, 779-816, https://doi.org/10.1007/s10712-012-9184-0, 2012.

Stevens, B., Fiedler, S., Kinne, S., Peters, K., Rast, S., Müsse, J., Smith, S. J., and Mauritsen, T.: MACv2-SP: a parameterization of anthropogenic aerosol optical properties and an associated Twomey effect for use in CMIP6, Geosci. Model Dev., 10, 433452, https://doi.org/10.5194/gmd-10-433-2017, 2017.

Storelvmo, T., Leirvik, T., Lohmann, U., Phillips, P. C. B., and Wild, M.: Disentangling greenhouse warming and aerosol cooling to reveal Earth's climate sensitivity, Nat. Geosci., 9, 286-289, https://doi.org/10.1038/ngeo2670, 2016.

Su, W., Loeb, N. G., Schuster, G. L., Chin, M., and Rose, F. G.: Global all-sky shortwave direct radiative forcing of anthropogenic aerosols from combined satellite observations and GOCART simulations, J. Geophys. Res.-Atmos., 118, 655-669, https://doi.org/10.1029/2012jd018294, 2013.

Taylor, K. E., Williamson, D., and Zwiers, F.: The sea surface temperature and sea-ice concentration boundary conditions for AMIP II simulations, Program for Climate Model Diagnosis and Intercomparison, Lawrence Livermore National Laboratory, University of California, Livermore, CA, USA, 2000.

Theil, H.: A rank-invariant method of linear and polynomial regression analysis. I, Nederl. Akad. Wetensch., Proc., 53, 386-392, 1950.

Twomey, S.: Pollution and the planetary albedo, Atmos. Environ., 8, 1251-1256, https://doi.org/10.1016/0004-6981(74)90004-3, 1974.

van der A, R. J., Mijling, B., Ding, J., Koukouli, M. E., Liu, F., Li, Q., Mao, H., and Theys, N.: Cleaning up the air: effectiveness of air quality policy for $\mathrm{SO}_{2}$ and $\mathrm{NO}_{x}$ emissions in China, Atmos. Chem. Phys., 17, 1775-1789, https://doi.org/10.5194/acp17-1775-2017, 2017.

van der Werf, G. R., Randerson, J. T., Giglio, L., van Leeuwen, T. T., Chen, Y., Rogers, B. M., Mu, M., van Marle, M. J. E., Morton, D. C., Collatz, G. J., Yokelson, R. J., and Kasibhatla, P. S.: Global fire emissions estimates during 1997-2016, Earth Syst. Sci. Data, 9, 697-720, https://doi.org/10.5194/essd-9-697-2017, 2017.

van Marle, M. J. E., Kloster, S., Magi, B. I., Marlon, J. R., Daniau, A.-L., Field, R. D., Arneth, A., Forrest, M., Hantson, S., Kehrwald, N. M., Knorr, W., Lasslop, G., Li, F., Mangeon, S., Yue, C., Kaiser, J. W., and van der Werf, G. R.: Historic global biomass burning emissions for CMIP6 (BB4CMIP) based on merging satellite observations with proxies and fire models (1750-2015), Geosci. Model Dev., 10, 3329-3357, https://doi.org/10.5194/gmd-10-3329-2017, 2017.

Wang, S., Xing, J., Jang, C., Zhu, Y., Fu, J. S., and Hao, J.: Impact Assessment of Ammonia Emissions on Inorganic Aerosols in East China Using Response Surface Modeling Technique, Environ. Sci. Technol., 45, 9293-9300, https://doi.org/10.1021/es2022347, 2011.

Wang, Y., Zhang, Q., Jiang, J., Zhou, W., Wang, B., He, K., Duan, F., Zhang, Q., Philip, S., and Xie, Y.: Enhanced sulfate formation during China's severe winter haze episode in January 2013 missing from current models, J. Geophys. Res.-Atmos., 119, 1042510440, https://doi.org/10.1002/2013JD021426, 2014.

Wang, Z., Schaaf, C. B., Strahler, A. H., Chopping, M. J., Román, M. O., Shuai, Y., Woodcock, C. E., Hollinger, D. Y., and Fitzjarrald, D. R.: Evaluation of MODIS albedo product (MCD43A) over grassland, agriculture and forest surface types during dormant and snow-covered periods, Remote Sens. Environ., 140, 60-77, https://doi.org/10.1016/j.rse.2013.08.025, 2014.

Warner, J. X., Dickerson, R. R., Wei, Z., Strow, L. L., Wang, Y., and Liang, Q.: Increased atmospheric ammonia over the world's major agricultural areas detected from space, Geophys. Res. Lett., 44, 2875-2884, https://doi.org/10.1002/2016GL072305, 2017.

Wielicki, B. A., Barkstrom, B. R., Harrison, E. F., Lee, R. B., Louis Smith, G., and Cooper, J. E.: Clouds and the Earth's Radiant Energy System (CERES): An Earth Observing System Experiment, B. Am. Meteorol. Soc., 77, 853-868, https://doi.org/10.1175/15200477(1996)077<0853:CATERE>2.0.CO;2, 1996.

Wielicki, B. A., Barkstrom, B. R., Baum, B. A., Charlock, T. P., Green, R. N., Kratz, D. P., Lee, R. B., Minnis, P., Smith, G. L., Wong, T., Young, D. F., Cess, R. D., Coakley, J. A., Crommelynck, D. A. H., Donner, L., Kandel, R., King, M. D., Miller, A. J., Ramanathan, V., Randall, D. A., Stowe, L. L., and Welch, R. M.: Clouds and the Earth's Radiant Energy System (CERES): 
algorithm overview, IEEE T. Geosci. Remote, 36, 1127-1141, https://doi.org/10.1109/36.701020, 1998.

Wild, M.: Global dimming and brightening: A review, J. Geophys. Res.-Atmos., 114, D00D16, https://doi.org/10.1029/2008JD011470, 2009.

Xing, J., Mathur, R., Pleim, J., Hogrefe, C., Gan, C.-M., Wong, D. C., and Wei, C.: Can a coupled meteorology-chemistry model reproduce the historical trend in aerosol direct radiative effects over the Northern Hemisphere?, Atmos. Chem. Phys., 15, 999710018, https://doi.org/10.5194/acp-15-9997-2015, 2015.

Yevich, R. and Logan, J.: An assessment of biofuel use and burning of agricultural waste in the developing world., Global Biogeochem. Cy., 17, 1095, https://doi.org/10.1029/2002GB001952, 2003.

Zhang, L., Chen, Y., Zhao, Y., Henze, D. K., Zhu, L., Song, Y., Paulot, F., Liu, X., Pan, Y., Lin, Y., and Huang, B.: Agricultural ammonia emissions in China: reconciling bottom-up and top-down estimates, Atmos. Chem. Phys., 18, 339-355, https://doi.org/10.5194/acp-18-339-2018, 2018.

Zhang, Q., Streets, D. G., Carmichael, G. R., He, K. B., Huo, H., Kannari, A., Klimont, Z., Park, I. S., Reddy, S., Fu, J. S., Chen, D., Duan, L., Lei, Y., Wang, L. T., and Yao, Z. L.: Asian emissions in 2006 for the NASA INTEX-B mission, Atmos. Chem. Phys., 9, 5131-5153, https://doi.org/10.5194/acp-9-5131-2009, 2009.
Zhao, B., Jiang, J. H., Gu, Y., Diner, D., Worden, J., Liou, K.N., Su, H., Xing, J., Garay, M., and Huang, L.: Decadalscale trends in regional aerosol particle properties and their linkage to emission changes, Environ. Res. Lett., 12, 054021, https://doi.org/10.1088/1748-9326/aa6cb2, 2017.

Zheng, B., Zhang, Q., Zhang, Y., He, K. B., Wang, K., Zheng, G. J., Duan, F. K., Ma, Y. L., and Kimoto, T.: Heterogeneous chemistry: a mechanism missing in current models to explain secondary inorganic aerosol formation during the January 2013 haze episode in North China, Atmos. Chem. Phys., 15, 2031-2049, https://doi.org/10.5194/acp-15-2031-2015, 2015.

Zhu, Z., Piao, S., Myneni, R. B., Huang, M., Zeng, Z., Canadell, J. G., Ciais, P., Sitch, S., Friedlingstein, P., Arneth, A., Cao, C., Cheng, L., Kato, E., Koven, C., Li, Y., Lian, X., Liu, Y., Liu, R., Mao, J., Pan, Y., Peng, S., Peñuelas, J., Poulter, B., Pugh, T. A. M., Stocker, B. D., Viovy, N., Wang, X., Wang, Y., Xiao, Z., Yang, H., Zaehle, S., and Zeng, N.: Greening of the Earth and its drivers, Nat. Clim. Change, 6, 791-795, https://doi.org/10.1038/nclimate3004, 2016. 